\title{
Slavek
}

\section{LANDSURFACE SUBSIDENCE IN THE AREA OF BURNETT, SCOTT, AND CRYSTAL BAYS NEAR BAYTOWN, TEXAS}

\section{U.S. GEOLOGICAL SURVEY}

Water-Resources Investigations 21-74

\section{REPORTS SECTION COPY}
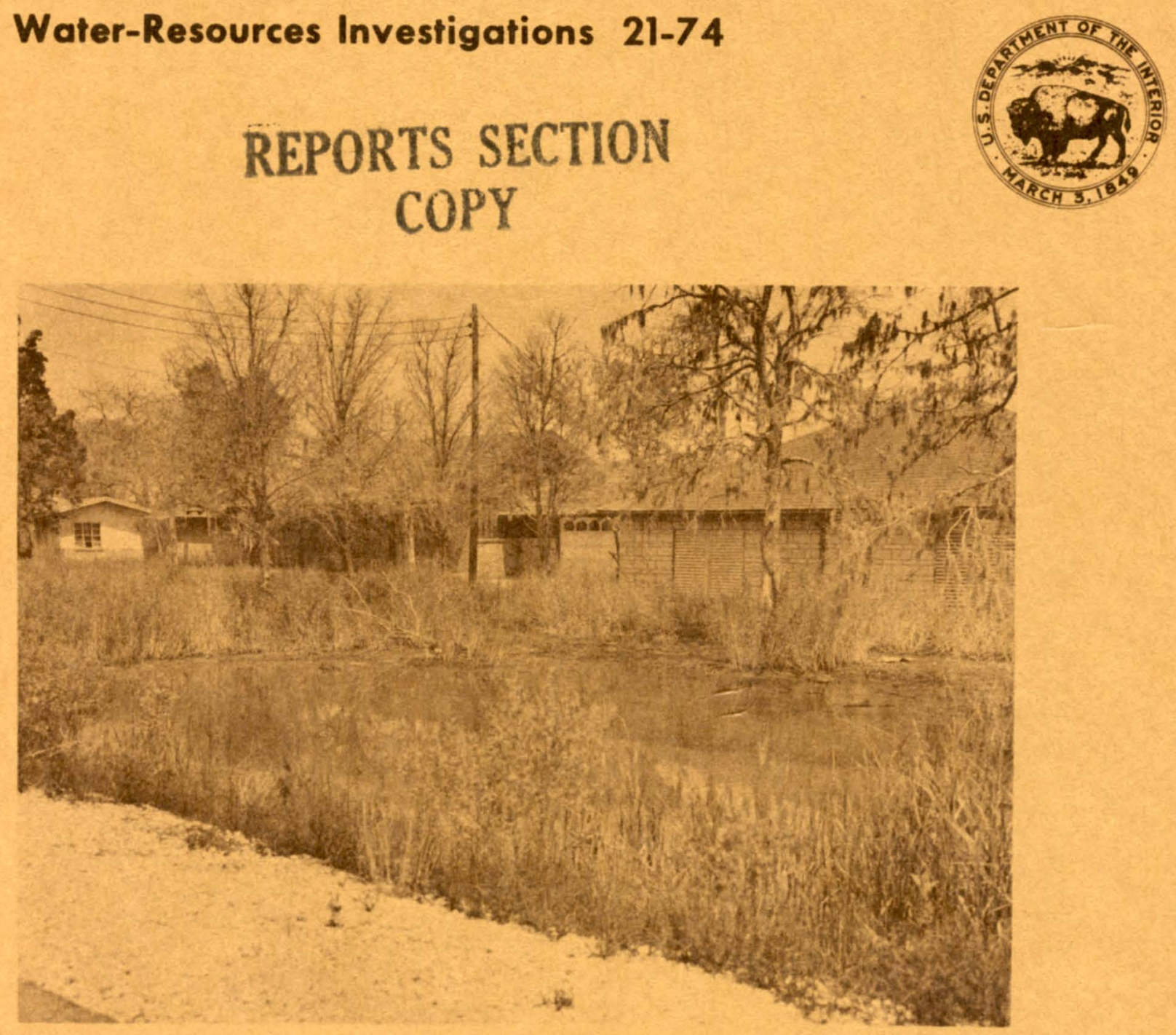

Prepared by the U.S. Geological Survey in cooperation with the U.S. Army Corps of Engineers 
4. Title and Subtitle

LAND-SURFACE SUBSIDENCE IN THE AREA OF BURNETT, SCOTT, AND CRYSTAL BAYS NEAR BAYTOWN, TEXAS

September 1974

6.

8. Performing Organization Rept. No. WRI $21-74$

R. K. Gabrysch and C. W. Bonnet

10. Project/Task/Work Unit No.

U.S. Geological Survey

Federal Building, 300 E. Eighth Street

11. Contract/Grant No.

Austin, TX 78701

12. Sponsoring Organization Name and Address

U.S. Geological Survey

Federal Building, 300 E. Eighth Street

Austin, TX 78701

13. Type of Report \& Period Covered

Final

14.

15. Supplementary Notes

Prepared in cooperation with the U.S. Army Corps of Engineers.

16. Abstracts Subsidence in the Baytown area is becoming critical because much of the area is subject to inundation by high tides. Withdrawals of water from industrial wells and declines in artesian pressures began about 1918. As much as 280 feet (85.3 meters) of artesian-head decline has occurred in the Evangeline aquifer, and as much as 320 feet ( 97.5 meters) of decline has occurred in the Alta Loma Sand. Subsidence of the land surface began about 1920, and as much as 8.2 feet (2.5 meters) of subsidence had occurred by 1973 .

Future subsidence was calculated for two loading situations. Case I provided that the artesian heads in the Alta Loma Sand and Evangeline aquifer would continue to decline at a rate of 6 feet ( 1.8 meters) per year until 1980. Case II provided that artesian head in the Alta Loma Sand and Evangeline aquifer would continue to decline at a rate of about 6 feet ( 1.8 meters) per year until about 1995. The ultimate subsidence expected for the assumed conditions of case I and case II is 11.4 feet ( 3.47 meters) and 15.1 feet (4.60 meters), respectively.

17. Key Words and Document Analysis. 17a. Descriptors

*Subsidence, *land-surface subsidence, compaction, artesian pressures,

water-level declines.

17b. Identifiers/Open-Ended Terms

Houston-Galveston region, Harris County, Texas.

17c. COSATI Field/Group

18. Availability Statement

No restriction on distribution.

19. Security Class (This Report)

UNCLASSIFIED

20. Security Class (This

Page

UNCLASSIFIED
21. No. of Pages 51

22. Price 
CONTENTS

Page

Abstract-1 1

Introduction-1... 3

Causes of subsidence-1. 5

Subsidence at Burnett, Scott, and Crystal Bays-_....... 10

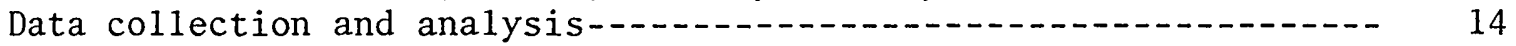

Predicted subsidence-_-_._. 21

Corrective measures-_._. 24

Selected references-_... 33 
Figure 1. Map showing location of Burnett, Scott, and

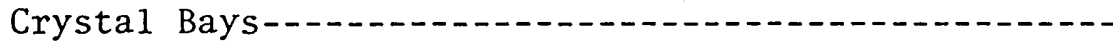

2. Map showing principal areas of ground-water pumping and average rate of withdrawal in 1972

3. Hydrologic profile showing aquifers, principal zones of ground-water withdrawal, altitudes of the potentiometric surfaces, and land-surface

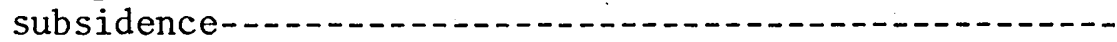

4. Hydrographs showing changes in water levels in wells completed in the Alta Loma Sand and graph showing subsidence of bench mark PTS 185-

5. Map showing approximate land-surface subsidence,

6. Map showing approximate land-surface subsidence, $1964-73-$

7. Graphs showing relation between land-surface subsidence and artesian-head decline-

8. Graph showing measured compaction and subsidence at the Johnson Space Center-...-

9. Electrical logs of wells in the study area-.....

10. Graph showing effective load at Burnett, Scott, and Crystal Bays-_...

11. Potentiometric profile at Baytown, March 1974-....

12.-27. Graphs showing:

12. Calculated land-surface subsidence, 1920-75-_.-.-.--

13. Calculated land-surface subsidence, 1920-2070-....-..-

14. Relation between void ratio and applied pressure for a clay sample from a depth of 141 feet $(43$

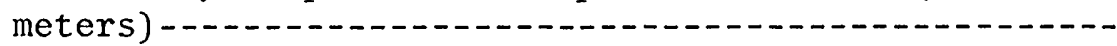

15. Relation between void ratio and applied pressure for a clay sample from a depth of 211 feet (64 meters) -

16. Relation between void ratio and applied pressure for a clay sample from a depth of 265 feet (81 meters) -

17. Relation between void ratio and applied pressure for a clay sample from a depth of 346 feet (105 meters)

18. Relation between void ratio and applied pressure for a clay sample from a depth of 541 feet (165 meters)

19. Relation between void ratio and applied pressure for a clay sample from a depth of 800 feet (244

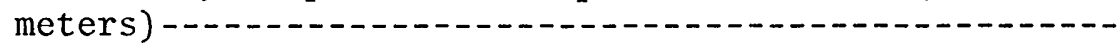

20. Relation between void ratio and applied pressure for a clay sample from a depth of 1,004 feet (306 
Figure 21. Relation between void ratio and applied pressure for a clay sample from a depth of 1,216 feet

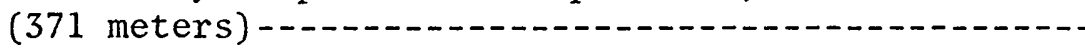

22. Relation between void ratio and applied pressure for a clay sample from a depth of 1,647 feet (502 meters)

23. Relation between consolidation and time for clay samples from depths of 140 and 210 feet (43 and 64 meters)

24. Relation between consolidation and time for clay samples from depths of 264 and 345 feet ( 80 and 105 meters)--.-.--

25. Relation between consolidation and time for clay samples from depths of 542 and 801 feet (165 and 244 meters)

26. Relation between consolidation and time for clay samples from depths of 1,004 and 1,216 feet (306 and 371 meters)

27. Relation between consolidation and time for a clay sample from a depth of 1,647 feet (502 meters)-..--- 
Table 1. Physical properties of clay samples-a

2. Coefficients of consolidation and hydraulic

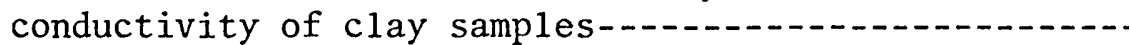


LAND-SURFACE SUBSIDENCE

IN THE AREA OF BURNETT, SCOTT, AND

CRYSTAL BAYS NEAR BAYTOWN, TEXAS

By

R. K. Gabrysch and C. W. Bonnet

U.S. Geological Survey

\section{ABSTRACT}

Removal of water, oil, and gas from the subsurface in Harris County has caused declines in fluid pressures, which in turn have resulted in subsidence of the land surface. Subsidence in the area of Burnett, Scott, and Crystal Bays near Baytown is becoming critical because much of the area is now subject to inundation by high tides.

Production of oil and gas from the Goose Creek Field on the southeast edge of Baytown had caused as much as 3.25 feet ( 1 meter) of subsidence by 1925. The subsidence due to oil and gas production is restricted to the area of production and has not extended to the area of Burnett, Scott, and Crystal Bays.

Withdrawals of water from large-capacity industrial wells, which resulted in declines in artesian pressure, began about 1918. As much as 280 feet ( 85.3 meters) of artesian-head decline has occurred in the Evangeline aquifer, and as much as 320 feet (97.5 meters) of artesianhead decline has occurred in the Alta Loma Sand of Rose (1943). Significant subsidence of the land surface probably began about 1920 or later and as much as 8.2 feet (2.5 meters) of subsidence had occurred in the area by 1973 .

The study of subsidence in the area of the three bays included the collection of undisturbed clay samples for laboratory analyses, collection of water-level records, and installation and monitoring of pressure transducers in clays and of observation wells in sands.

Probable future subsidence was calculated for two loading situations. Case I provided that the artesian head in both the Alta Loma Sand and Evangeline aquifer would continue to decline at a rate of 6 feet $(1.8$ meters) per year until 1980 and then cease. Case II provided that artesian head in the Alta Loma Sand would continue to decline at a rate of about 6 feet (1.8 meters) per year until about 1995, when the potentiometric surface would reach the top of the Alta Loma Sand. The artesian head in the Evangeline aquifer would also decline about 6 feet ( 1.8 meters) per year until 1995 . 
The ultimate subsidence expected for the assumed conditions of case $I$ and case II is 11.4 feet (3.47 meters) and 15.1 feet ( 4.60 meters), respectively. However, only 1.4 feet ( 0.43 meter) of subsidence below present land surface would occur if artesian heads were maintained at their present leve1s.

To halt subsidence in the near future, artesian head must be increased, either by decreasing pumpage or by repressurization by artificial recharge. 


\section{INTRODUCTION}

The pumping of vast quantities of ground water to meet the increasing demands for industrial use, irrigation, and municipal supply in Harris County has caused significant declines in artesian heads. The declines in artesian heads have in turn caused critical subsidence of the land surface in parts of the county. One such area of critical land-surface subsidence is in the area of Burnett, Scott, and Crystal Bays near Baytown in the eastern part of Harris County (fig. 1).

The land surface in this area has subsided several feet since development of ground water began, and some parts have been inundated by seawater. Driveways, streets, and some homes along the waterfront are flooded regularly by normal high tides. Unusually high tides, such as those produced by Hurricane Carla in 1961, flood everything at an elevation of less than about 13 feet ( 4 meters) above mean sea level.

At the request of the U.S. Army Corps of Engineers, the U.S. Geological Survey began an investigation in March 1972 of land-surface subsidence in the area of Burnett, Scott, and Crystal Bays. The objectives of this investigation are:

1. To determine the amount of subsidence due to the withdrawal of oil and gas and the amount due to the withdrawal of water.

2. To determine the rates of subsidence due to each cause and to relate the rate of subsidence to the decline in artesian heads.

3. To predict the decline in artesian head during the next 50 years.

4. To predict the rate of subsidence caused by each type of fluid withdrawal.

5. To predict the maximum subsidence to be expected during the next 50 years.

A report of preliminary findings (Gabrysch, 1972) included predictions of subsidence based on consolidation tests of four undisturbed clay samples taken from layers above the Alta Loma Sand of Rose (1943) at Baytown and of four undisturbed clay samples from a test well at the University of Houston.

The calculated amounts of subsidence agreed favorably with measured changes in altitude of a nearby bench mark. However, it was not known: (1) If the characteristics of the clays at the University of Houston site were representative of those at the Baytown site; (2) if available electrical logs near Baytown adequately described the subsurface at the Baytown site; or (3) if the maps showing the approximate regional decline in artesian head could be used. Therefore, clay samples were obtained for consolidation tests, and artesian heads were determined for the section below the Alta Loma Sand. 
The authors gratefully acknowledge the assistance of Mr. Spencer Buchanan and Robert Bigham of Spencer J. Buchanan and Associates, Inc.; $\mathrm{Mr}$. Jerry Dvorak and Andy Branswell of the Exxon Company, USA; Mr. C. M. Floyd, consulting engineer; and Mr. Baker Birdwe11, Birdwell's Water Well Service. The city of Baytown, through Mr. Jack Morton, director of public works, furnished the site for installation of monitoring equipment.

For those readers interested in using the metric system, metric equivalents of English units of measurements are given in parentheses. The English units used in this report may be converted to metric units by the following conversion factors:

foot $(f t)$

inch (in)

mile (mi)

million gallons per day

(mgd)

pound per square inch

(psi)

square foot $\left(\mathrm{ft}^{2}\right)$

square inch $\left(\mathrm{in}^{2}\right)$

ton per square foot

(ton $/ \mathrm{ft}^{2}$ )
0.3048

2.540

1.609

0.04381

0.0703

0.0929

6.452

0.9765 meter ( $m$ ) centimeter $(\mathrm{cm})$

kilometer $(\mathrm{km})$

cubic meter per second $\left(\mathrm{m}^{3} / \mathrm{s}\right)$

kilogram per square

centimeter $\left(\mathrm{kg} / \mathrm{cm}^{2}\right)$

square meter $\left(\mathrm{m}^{2}\right)$

square centimeter $\left(\mathrm{cm}^{2}\right)$

kilogram per square meter $\left(\mathrm{kg} / \mathrm{m}^{2}\right)$

\section{CAUSES OF SUBSIDENCE}

In the Baytown area, there are two primary causes of 1 and-surface subsidence--the withdrawal of oil and gas and the pumping of ground water.

As early as 1918, subsidence due to oil and gas production was noticed at the Goose Creek Field on the southeast edge of Baytown. According to Pratt and Johnson (1926), the subsidence "bowl" was about 2.5 miles (4.0 kilometers) 1 ong and 1.5 miles ( 2.4 kilometers) wide by 1925 . Subsidence at the center was about 3.25 feet ( 1 meter).

In 1925, oil and gas were produced from depths between 1,000 and 4,100 feet ( 305 and 1,250 meters) below land surface. In 1973, production was from 23 separate zones between 1,500 and 5,000 feet ( 457 and 1,524 meters). The production is from zones that probably have little hydraulic continuity; therefore, the declines in heads are restricted principally to the zones of withdrawal, and subsidence of the land surface is restricted to the area of the field. 
Because the distance from Scott Bay to the western edge of the Goose Creek Field is about 2.5 miles ( 4.0 kilometers), none of the subsidence in the area of the bays is attributed to oil and gas production.

Figure 2 shows the location of the principal areas of ground-water pumping and the average rate of withdrawal in 1972 for the region surrounding the area of Burnett, Scott, and Crystal Bays.

Ground water in the region is being withdrawn from two principal aquifers, the Chicot and Evangeline. Figure 3 shows the depths and thicknesses of the aquifers, the approximate zones of withdrawal, the altitudes of the potentiometric surface, and subsidence along a line from about 60 miles (97 kilometers) west to about 20 miles ( 32 kilometers) east of the study area.

Ground-water withdrawals from large-capacity industrial wells began in the Baytown area about 1918. The pumpage increased from about. $5 \mathrm{mgd}$ $\left(0.219 \mathrm{~m}^{3} / \mathrm{s}\right)$ in 1919 to about $9 \mathrm{mgd}\left(0.394 \mathrm{~m}^{3} / \mathrm{s}\right)$ in 1927 . From 1928 to 1946 , the average was about $15 \mathrm{mgd}\left(0.657 \mathrm{~m}^{3} / \mathrm{s}\right)$; from 1946 to 1960 , the pumpage gradually increased to about $22 \mathrm{mgd}\left(0.964 \mathrm{~m}^{3} / \mathrm{s}\right)$. The withdrawal rate remained at about $22 \mathrm{mgd}\left(0.964 \mathrm{~m}^{3} / \mathrm{s}\right)$ until 1969 , when it increased to about $28 \mathrm{mgd}\left(1.23 \mathrm{~m}^{3} / \mathrm{s}\right)$. In 1972, pumpage of ground water was about $32 \mathrm{mgd}\left(1.40 \mathrm{~m}^{3} / \mathrm{s}\right)$.

Most of the withdrawals in the area are from wells completed in the Alta Loma Sand (lower unit of the Chicot aquifer), but the declines in artesian heads are not due to production of ground water in the Baytown area alone. Large-scale production of ground water from the Alta Loma Sand and the underlying Evangeline aquifer in the Pasadena area immediately west of the Baytown area has caused regional declines in artesian heads that extend to the Baytown area.

The decline in artesian head in the Evangeline aquifer at Baytown is principally the result of ground-water pumping at Pasadena. The decline in artesian head in the Alta Loma Sand is the result of pumping at Pasadena and at Baytown. In addition, the pumping of approximately $600 \mathrm{mgd}$ (26.3 $\mathrm{m}^{3} / \mathrm{s}$ ) in Harris County and parts of the adjoining counties has also contributed to the declines in artesian head at Baytown.

The artesian-head declines are illustrated by the hydrographs of wells in or near the Baytown area (fig. 4). We11 LJ-65-16-801, west of Burnett Bay, is between the centers of the cones of depression at Baytown and Pasadena. This hydrograph represents a long-term record of the changes in water levels (artesian-head declines) at a well near the monitoring site. In general, the hydrograph shows the same pattern of decline after 1962 as the hydrograph of well LJ-65-16-904, which is at the monitoring site. However, water levels in the well at the monitoring site are consistently 40 feet (12 meters) lower because of its proximity to the center of pumping. 


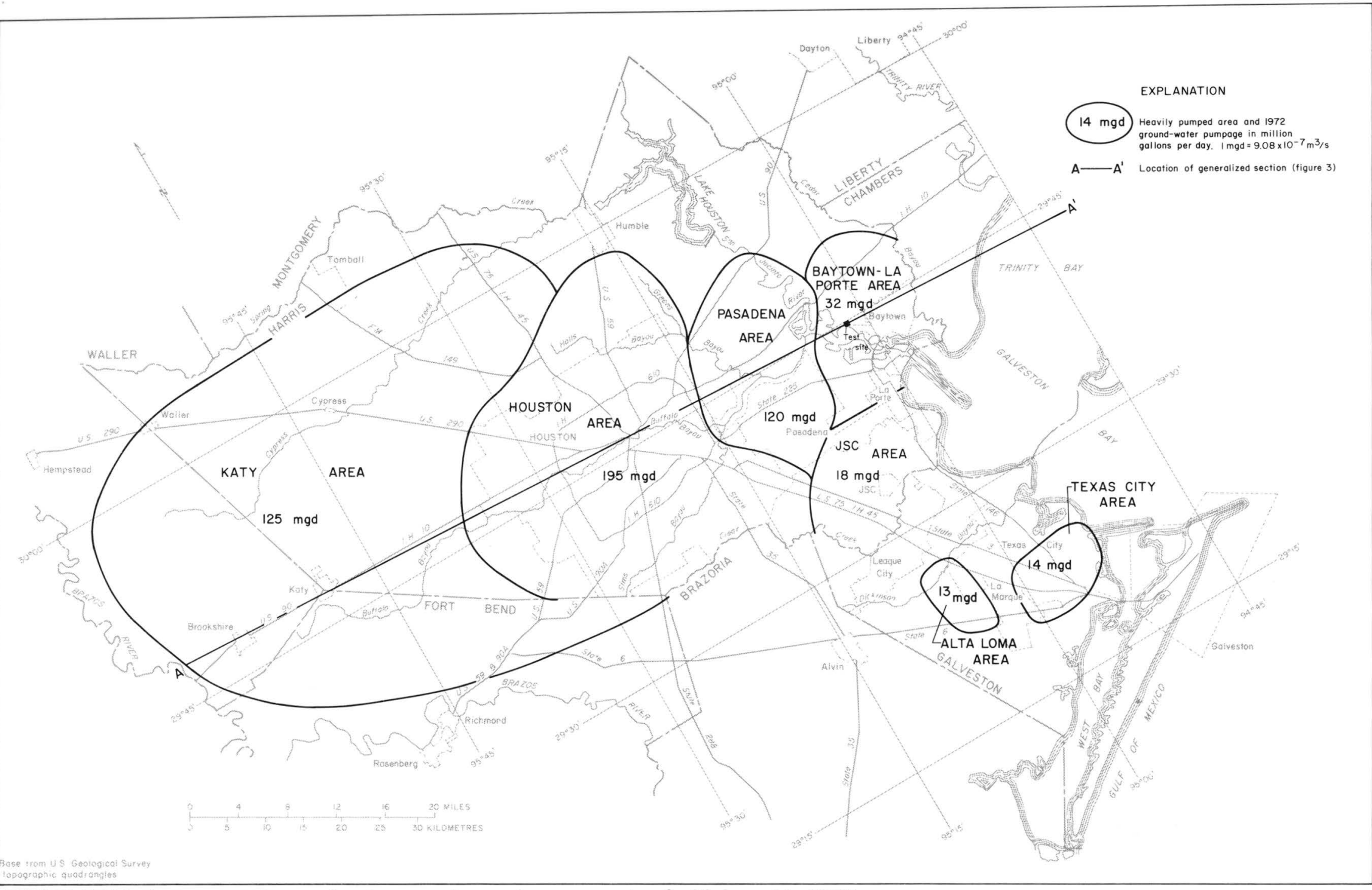

FIGURE 2.-Principal areas of ground-water pumping and average rate of withdrawal in 1972 


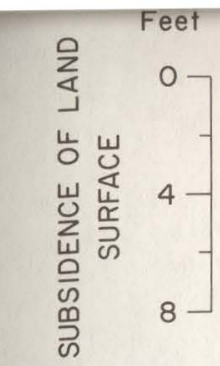

$$
-
$$

(n)

Sea
level

A

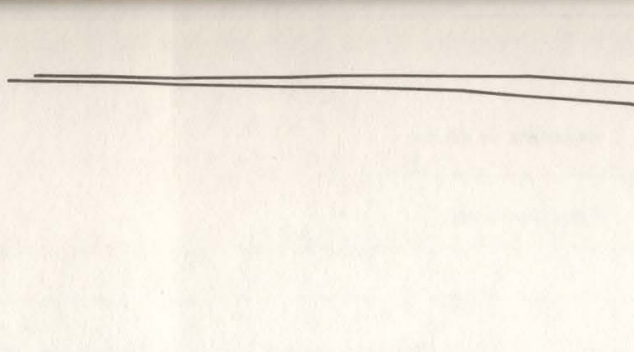

Subsidence 1964-73

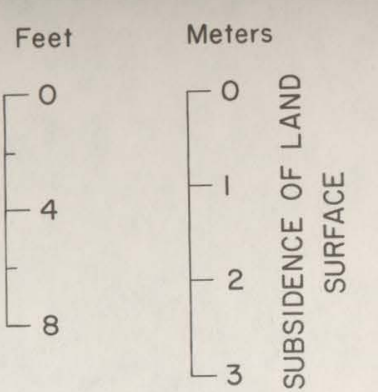

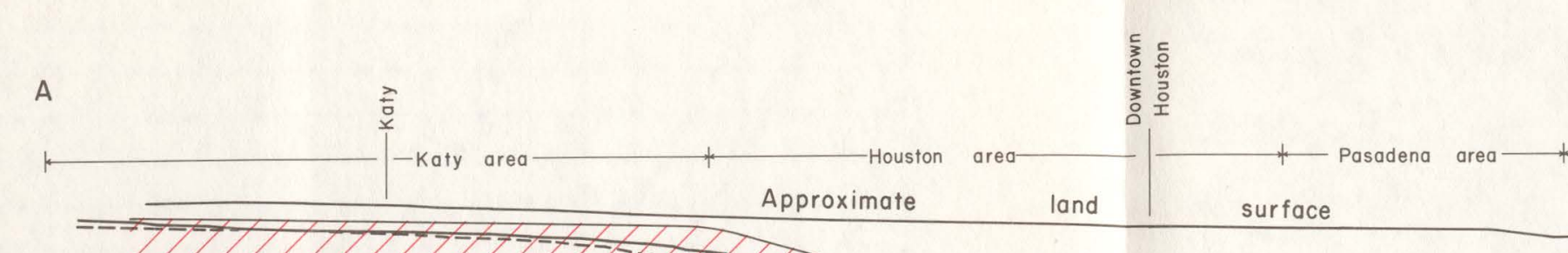

s.

$A^{\prime}$

$-200$

-400
sea
level
-400
-800
-1200
-1600
-2000
-2400
-2800
-3200
-3600
-4000

$-100$

Sea

leve

$-100$

$-200$

$-300$

$-400$

confining

EXPLANATION

layer

Approximate zone of principal

ground-water withdrawal

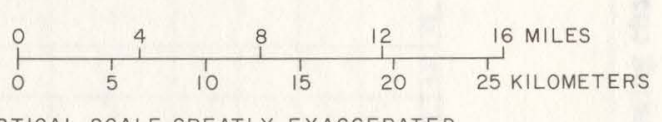

VERTICAL SCALE GREATLY EXAGGERATED

4000

FIGURE 3.-Hydrologic profile showing aquifers, principal zones of ground-water withdrawal, altitudes of the pe 


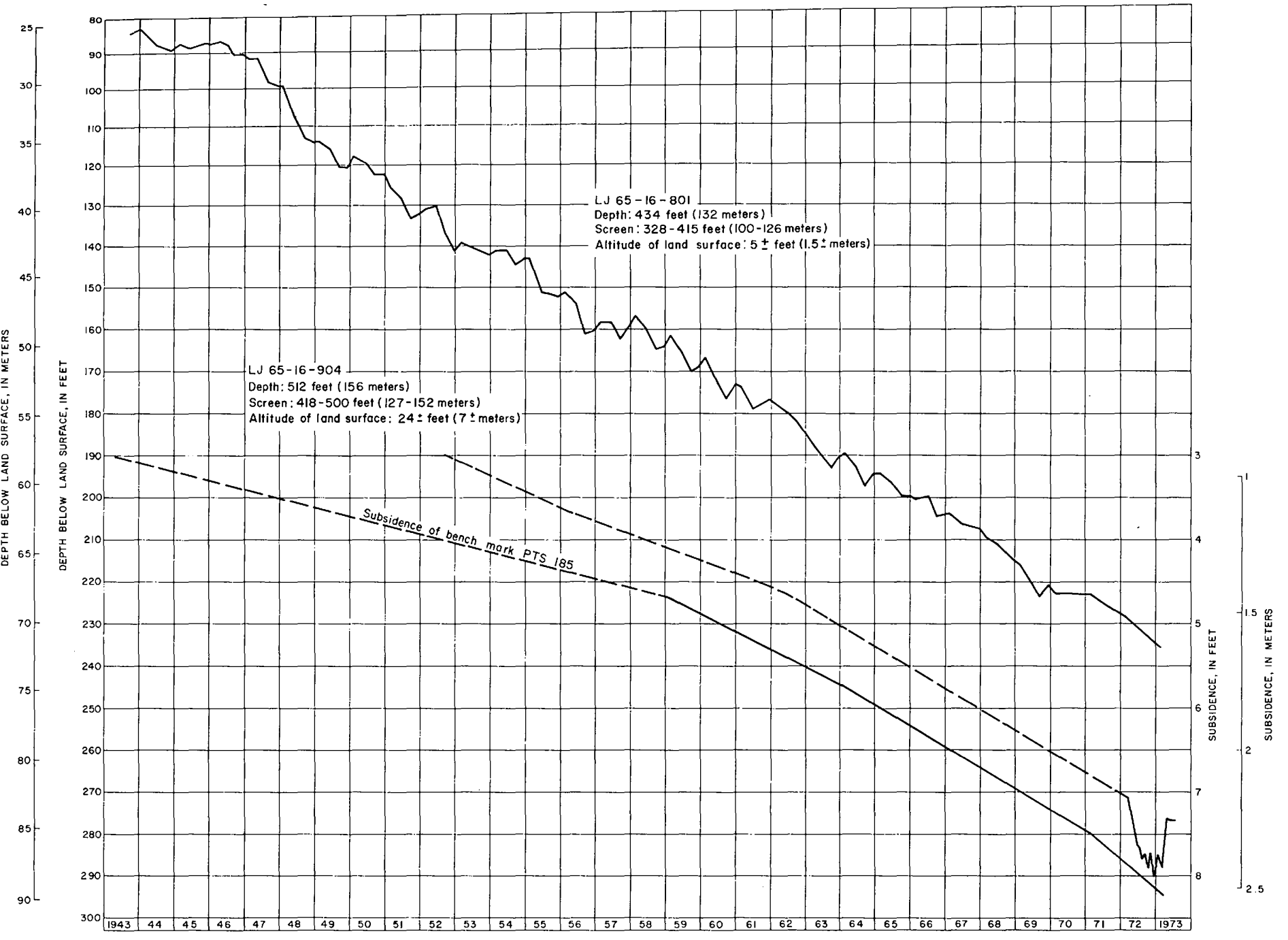


Since 1964, the rate of water-level decline indicated by regional contour maps (not included in this report) is about 6 feet ( 1.8 meters) per year; the rate indicated by the hydrographs is about 5 feet $(1.5$ meters) per year. For the period 1890 to 1970 , the total water-level decline in the Evangeline aquifer at the monitoring site has been as much as 280 feet ( 85.3 meters); the total water-level decline in the Alta Loma Sand has been as much as 320 feet ( 97.5 meters).

\section{SUBSIDENCE AT BURNETT, SCOTT, AND CRYSTAL BAYS}

Winslow and Doyel (1954) were probably the first to assemble data on subsidence in the Houston-Galveston region. Winslow and Wood (1959) added to the earlier findings when data became available. Gabrysch (1969) presented an analysis of subsidence in the region on the basis of the 1964 releveling of bench marks by the U.S. Coast and Geodetic Survey. Releveling of bench marks in the Baytown area was completed by the Corps of Engineers in 1971. The National Geodetic Survey redetermined the altitude of bench marks in the Houston-Galveston region in the spring of 1973. These and all other available data were used to prepare the maps showing 1and-surface subsidence for 1943-73 and 1964-73 (figs. 5 and 6).

Between 1943 and 1973, land-surface subsidence ranged from about 5.5 feet ( 1.68 meters) on the eastern side of the study area to about 6 feet ( 1.83 meters) on the extreme western side (fig. 5). Some subsidence occurred prior to 1943 , but information is too meager to prepare a contour map showing pre-1943 subsidence. Subsidence in the area of Burnett, Scott, and Crystal Bays ranged from 2 to 3 feet ( 0.61 to 0.91 meter) between 1964 and 1973 (fig. 6). The configuration of the 2-foot (0.6meter) contour at the Goose Creek Oil Field indicates some subsidence due to oil and gas production (fig. 6). The change in altitude of bench mark PTS 185 (fig. 12) indicates that the land surface on the northern edge of Scott Bay had subsided as much as 8.2 feet (2.5 meters) between 1915 and 1973.

The relationship between the decline in artesian head and subsidence of the land surface is shown on figure 7. The original artesian heads for the Alta Loma Sand and the Evangeline aquifer used in estimating decline are assumed values. The assumptions for the Evangeline aquifer are based on interpretations of published and unpublished regional waterlevel maps because there are no suitable observation we1ls in the area. 


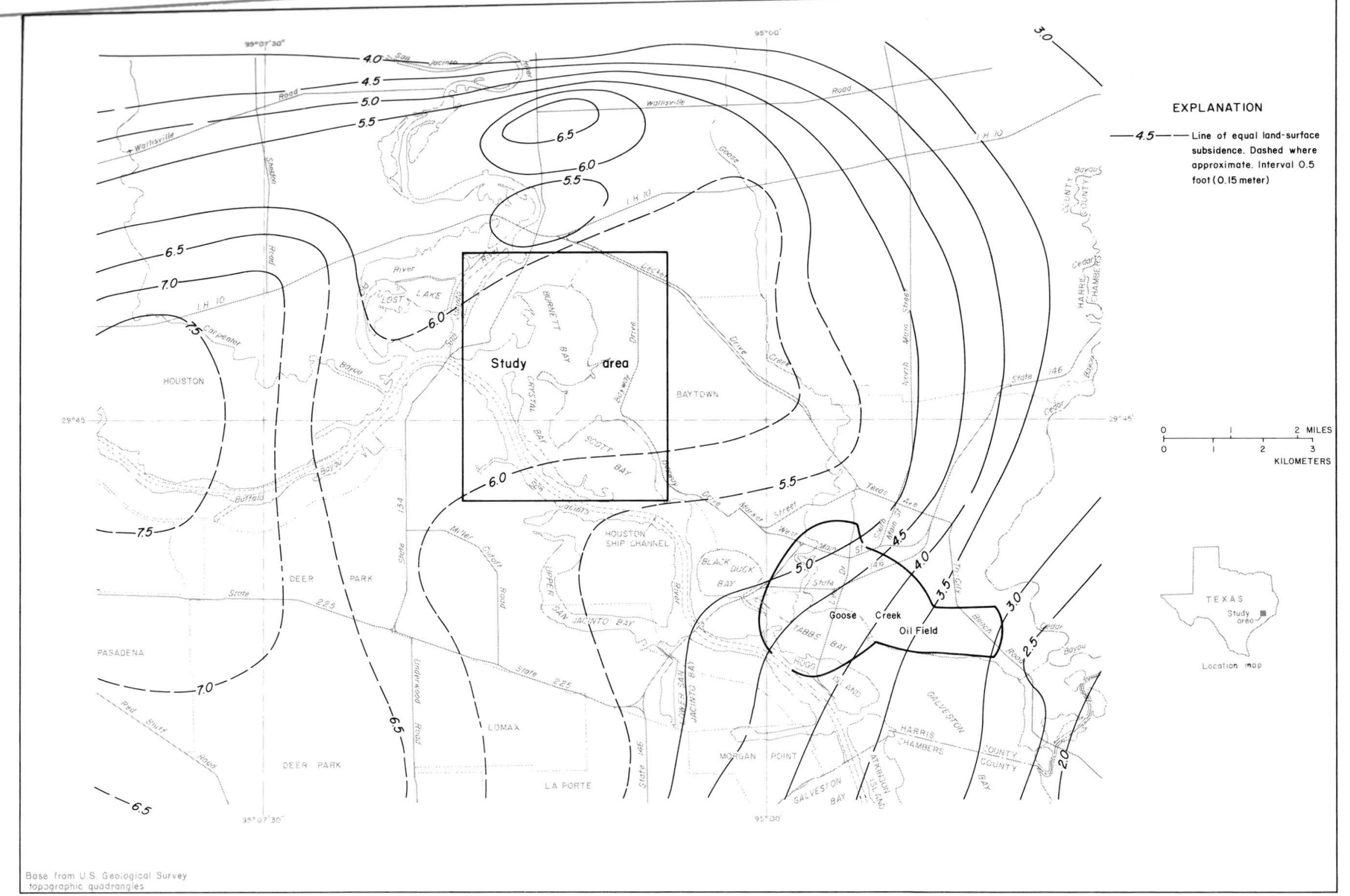




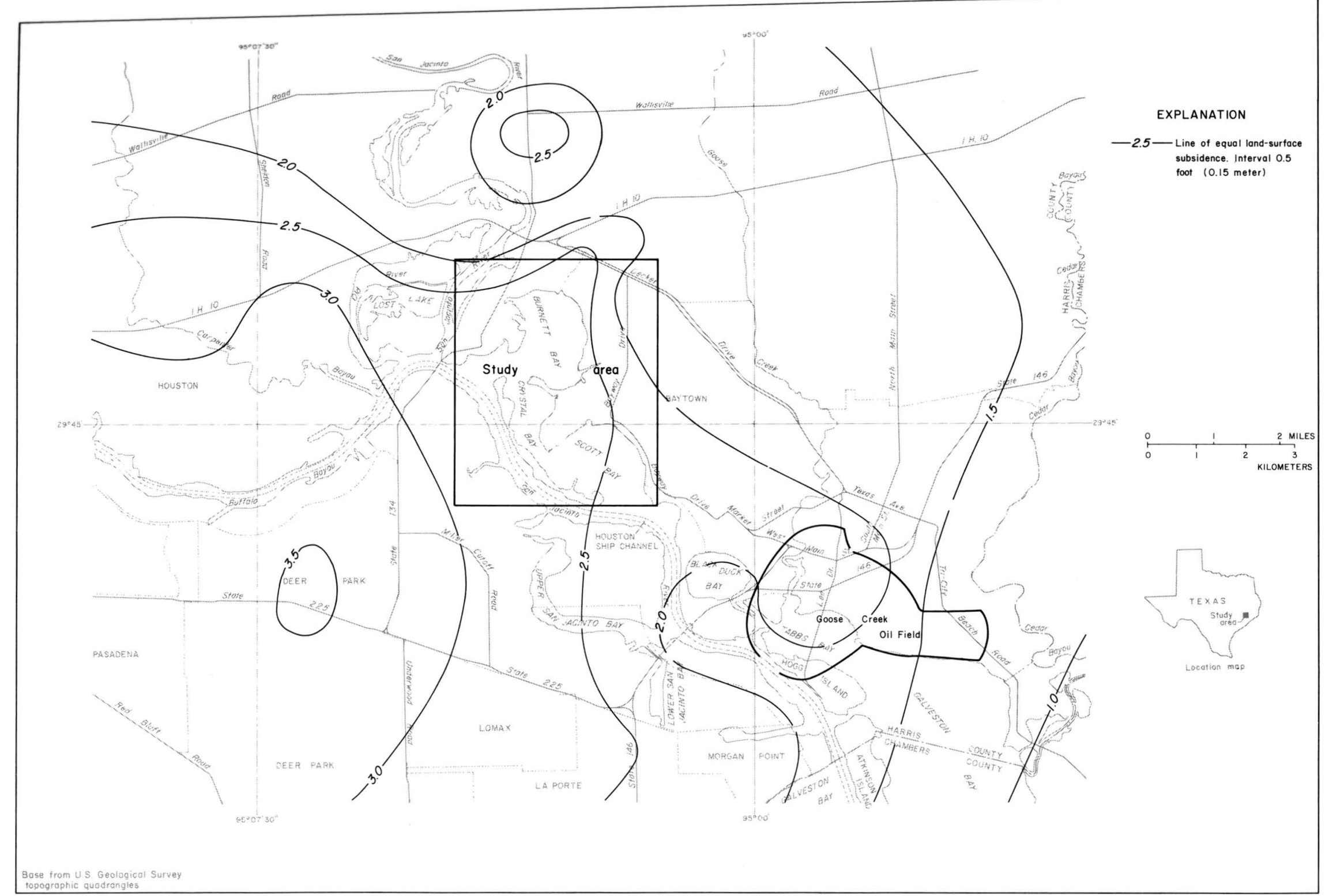

FIGURE 6.-Approximate land-surface subsidence, 1964-73 


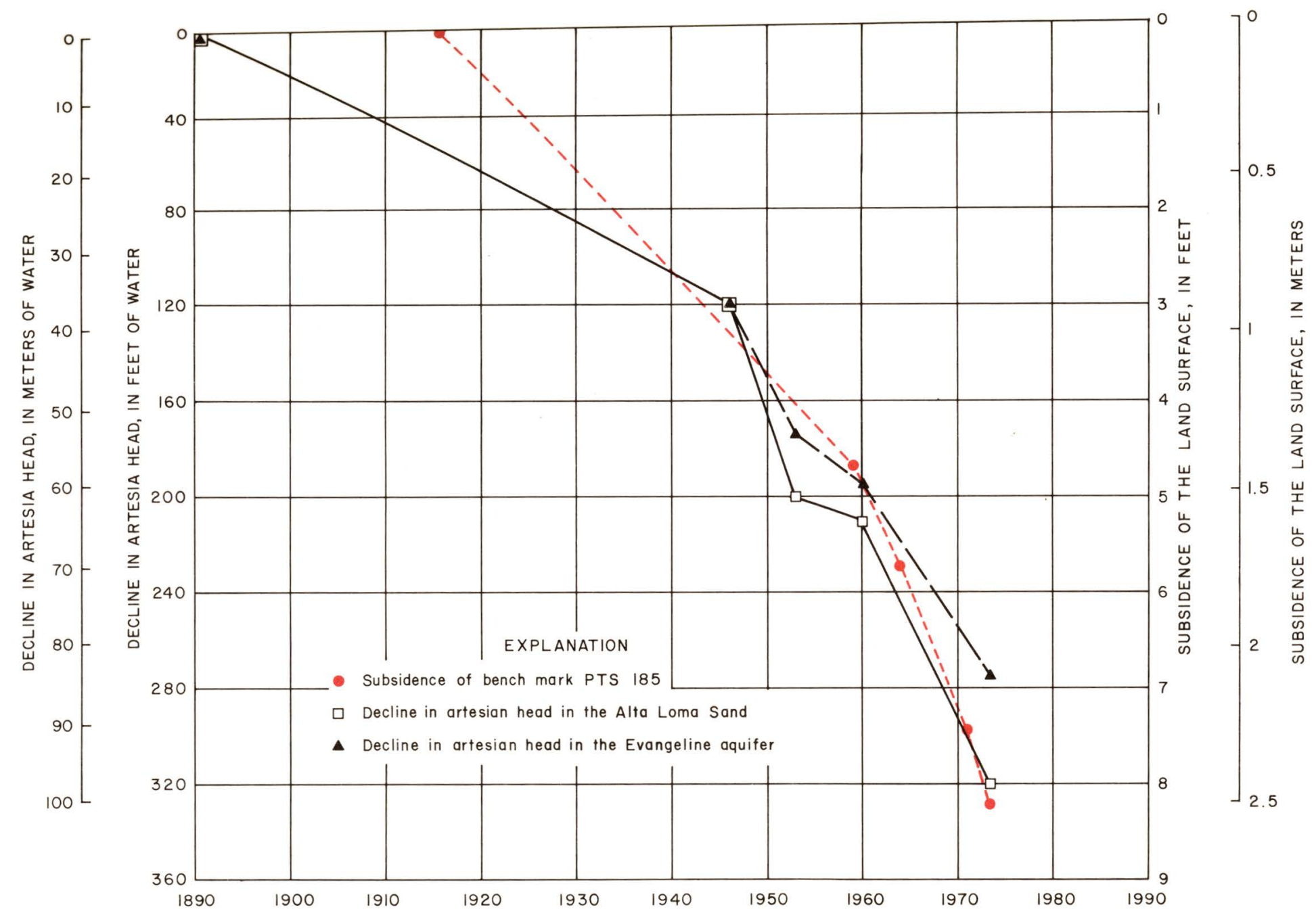

FIGURE 7.-Relation between land-surface subsidence and artesian-head decline 
Care must be exercised, however, in the projection of subsidence curves on the basis of pressure declines only. The ratio of subsidence to the decline of water levels in wells is not constant. For example, Gabrysch (1969, fig. 10) showed a range of 0.5 foot ( 0.15 meter) to more than 2.5 feet ( 0.76 meter) of subsidence per 100 feet (30.48 meters) of water-level decline in the Houston-Galveston region. The variation in the ratio is caused by the difference in total clay thickness, individual clay-bed thickness, and clay characteristics. The depth of the overburden and the amount of load to which the material has been previously subjected must also be considered.

Graphs showing the change in altitude of bench mark N646 and measured compaction of the subsurface material to a depth of 750 feet (229 meters) at the Johnson Space Center are shown on figure 8 . The graphs indicate that 62 percent of the subsidence between 1962 and 1973 was the result of compaction of the shallow clay beds.

\section{DATA COLLECTION AND ANALYSIS}

Because compaction of the subsurface material is dependent on the characteristics of the fine-grained material (chiefly clay) that is being compacted and the load to which the material is being subjected, undisturbed clay samples were collected at various depths. Four samples were analyzed by the U.S. Geological Survey laboratory in Denver, Colorado, and four samples were analyzed by Texas A \& M University, College Station, Texas, to determine Atterburg limits, moisture content, and unit weights. Consolidation tests were made as part of the analyses, and the permeability of each sample was determined. The results of a consolidation test of a clay sample collected at a depth of 1,647 feet (502 meters) at the University of Houston, about 19 miles (30 kilometers) west of the Baytown site, was used because a clay sample from that depth was not available at Baytown. Stratigraphically, the depth sampled at Houston represents a depth of about 2,100 feet (640 meters) at Baytown.

The samples at Baytown were taken from clay layers at depths of about $141,211,265,346,541,800,1,004$, and 1,216 feet $(42.9,64.3,80.8$, $105.5,164.9,243.8,306.0$, and 370.6 meters). Results of the laboratory tests are shown on figures 14-27 at the end of this report and given in tables 1-3. The hydraulic conductivity (permeability) for samples 1-4 was measured; the hydraulic conductivity for samples 5-9 was calculated (table 2). 


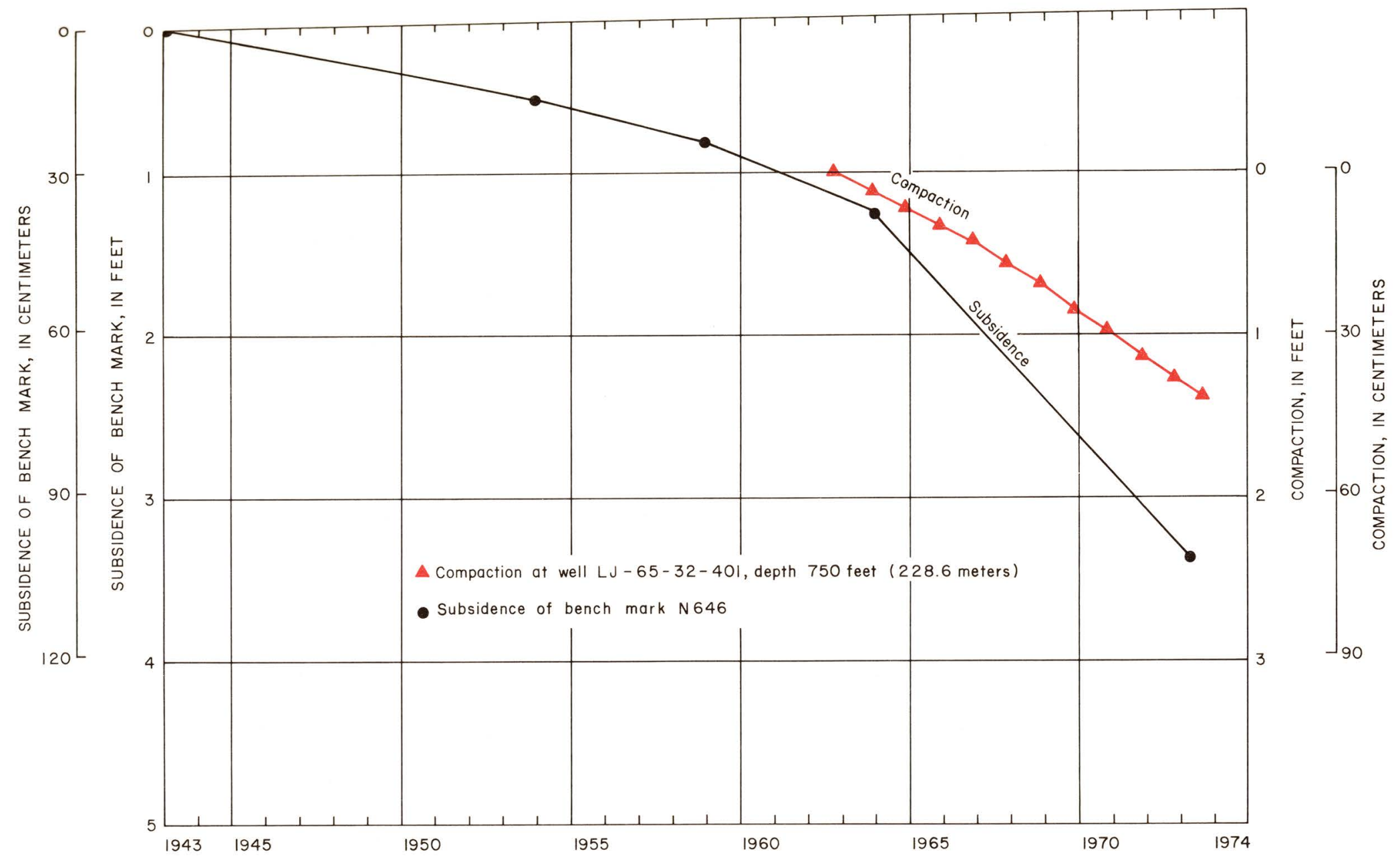

FIGURE 8.-Measured compaction and subsidence at the Johnson Space Center 
Electrical logs run at the monitoring site and at nearby wells were used to determine the thickness of the clay beds. Figure 9 shows the electrical logs of a well at the site and at a nearby well used in the interpretation. On the basis of these logs, the clays from the land surface to a depth of 2,500 feet (762 meters) (near the base of the Evangeline aquifer) were grouped into 68 layers (table 3 ). The clay beds ranged in thickness from 2 feet ( 0.6 meter) to 49 feet (14.9 meters). Sixty-two of the beds were less than 20 feet ( 6.1 meters) thick. Because the decline in artesian head and the compressibility of the clay below the Evangeline aquifer are probably negligible, compaction below 2,500 feet (762 meters) was assumed to be negligible. Data from the laboratory analyses of the clay samples (table 2) and data from the test well at the University of Houston were used to assign physical properties to the 68 clay layers.

The laboratory consolidation tests were used to relate the changes in loads imposed on a sample to the changes in voids in the sample material. By imposing several different loads on each sample, a curve of void ratio (ratio of voids to solids) versus the logarithm of load is obtained. The ultimate compaction (consolidation) of a clay layer may be computed by use of the basic formula of soil mechanics:

$$
S=(H) \frac{\Delta e}{1+e_{o}}
$$

where $S$ = compaction of the clay layer,

$\mathrm{H}=$ thickness of the clay layer,

$e_{0}=$ initial void ratio, and

$\Delta \mathrm{e}=$ change in void ratio caused by change in pressure.

The effective loads on the clay layers at Baytown were calculated by using soil weights as determined in the laboratory and artesian heads as determined from the regional maps. The effective loads in 1973 were based on pressure measurements at the monitoring site. The effective load at Burnett, Scott, and Crystal Bays is shown on figure 10.

By using the void ratio-loading curve and the loading due to declines in artesian heads, each clay layer was analyzed for its change in thickness according to the procedure outlined by Terzaghi and Peck (1948) and by Taylor (1948). The compaction of all clay layers was then summed to determine ultimate subsidence. It was assumed that the laboratory determined properties of a particular sample represented the properties of all clay layers in a depth interval from midway between the nearest samples above and below. 
Microlog

$\underset{-H+1}{20 m v} \quad 40$
Electrical log

$\stackrel{20 m v}{H}+\stackrel{P}{\circ}$ 100

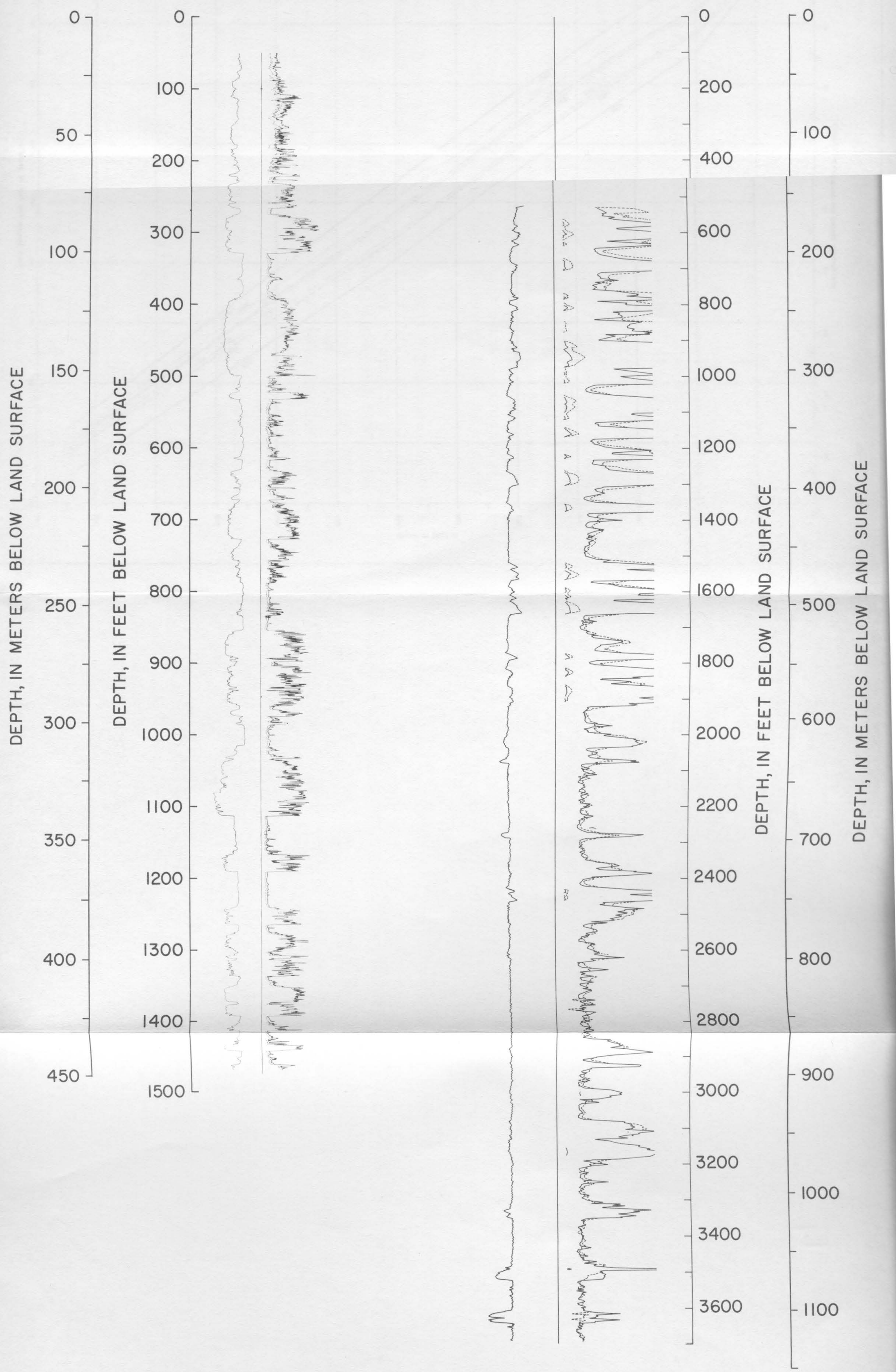




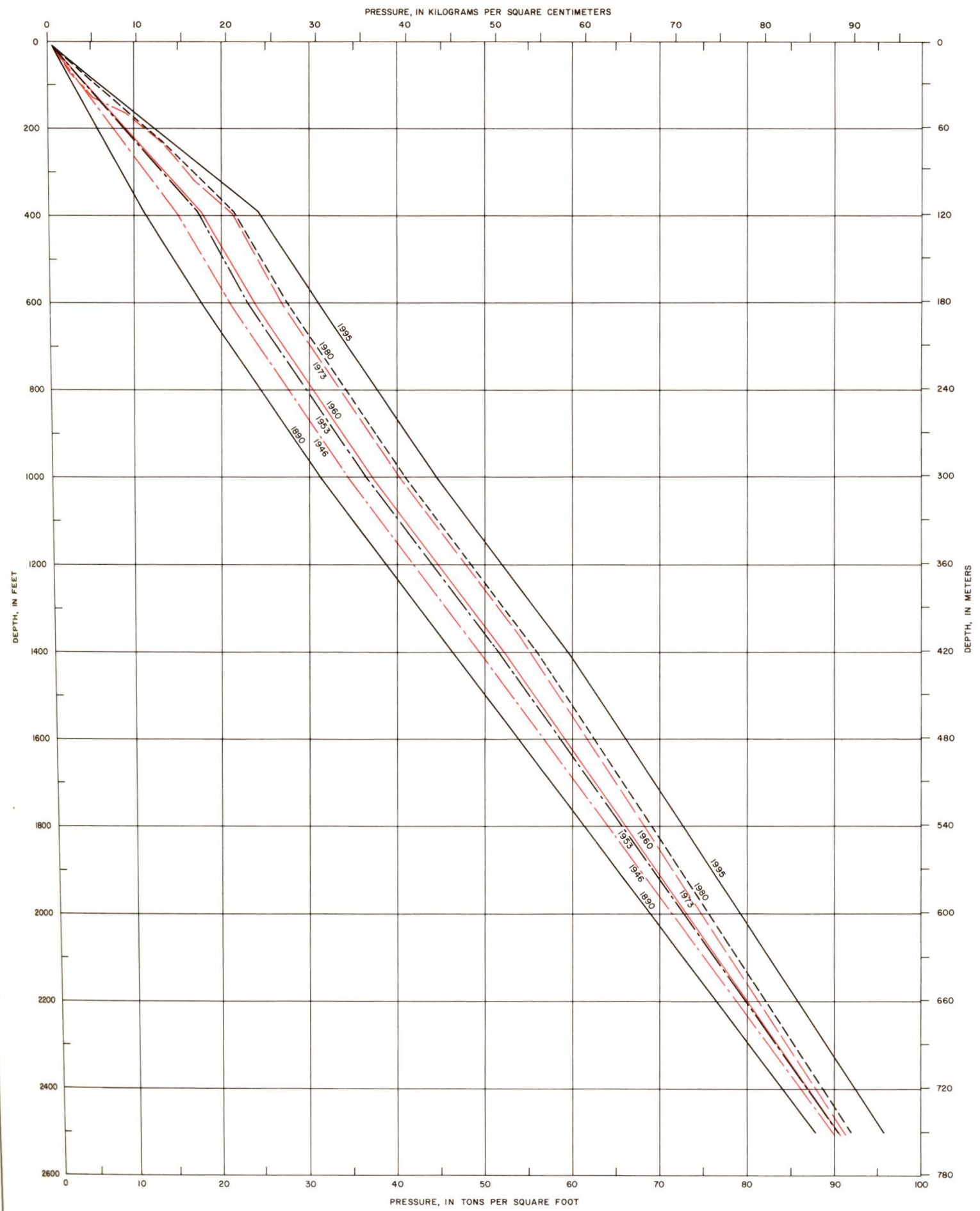

FIGURE 10.Effective load at Burnett, Scott, and Crystal Bays 
The time lag between loading and ultimate consolidation is dependent upon the thickness and permeability of the clay bed. The degree of consolidation at any time was determined as follows: Time factor, $T$, was computed from the formula

$$
T=\frac{c_{V}}{(H / 2)^{2}} t
$$

where $\mathrm{T}=$ dimensionless time factor,

$c_{v}=$ coefficient of consolidation from consolidation test, and

$t=$ time period of interest.

Using the calculated time factor, the degree of consolidation was obtained from the graph presented by Taylor (1948, fig. 10.10, p. 237). Corrections for incremental continuous loading rather than instantaneous loading were made according to the procedure outlined by Taylor (1948, p. 291).

The results of these calculations reflect compaction due to dissipation of excess pore pressure only. Riley (1969, p. 425), in his description of subsidence in California, considers secondary, or nonhydrodynamic, consolidation to be minor. The hydrogeologic setting in the area described by Riley is similar to the Baytown area. Also, the agreement between the calculations of subsidence based on dissipation of excess pore pressure and measured subsidence in the study area over a period of about 58 years leads to the conclusion that subsidence may be adequately described by examination of hydrodynamic consolidation. Secondary effects are considered to be minor.

Gross approximations of the declines in artesian pressures in the Alta Loma Sand and the Evangeline aquifer at the monitoring site were made from historical data on published and unpublished maps showing the altitudes of the potentiometric surfaces in 1890,1946,1953,1960, and 1970. The potentiometric surface, which is defined by the levels to which water will rise in tightly cased wells, is a surface that represents the static head. Loading of the clays was estimated for the assumed original conditions, and changes in loading were computed from the maps showing changes in artesian heads.

The current (1973) loading profile is based on measurements in seven observation wells and on data from four pneumatic pressure transducers that were installed in clay beds especially for this study. The measurements made in March 1974 were plotted against the depth of the well or transducer (fig. 11). This figure is presented to illustrate the wide variability of water levels that exist at a particular location.

The observation wells were drilled to depths of $110,170,234,324$, $430,1,365$, and 1,475 feet $(33.5,51.8,71.3,98.8,131.1,416.1$, and 449.6 meters) below land surface and were screened in sands in the bottom 10 feet ( 3 meters). The transducers were installed to measure pore pressure in clays at depths of $71,126,259$, and 344 feet $(21.6,38.4,78.9$, and 104.9 meters) below land surface. Instrumentation at the monitoring site may also permit estimation of the time lag between loading and drainage of the clays, which leads to compaction. 


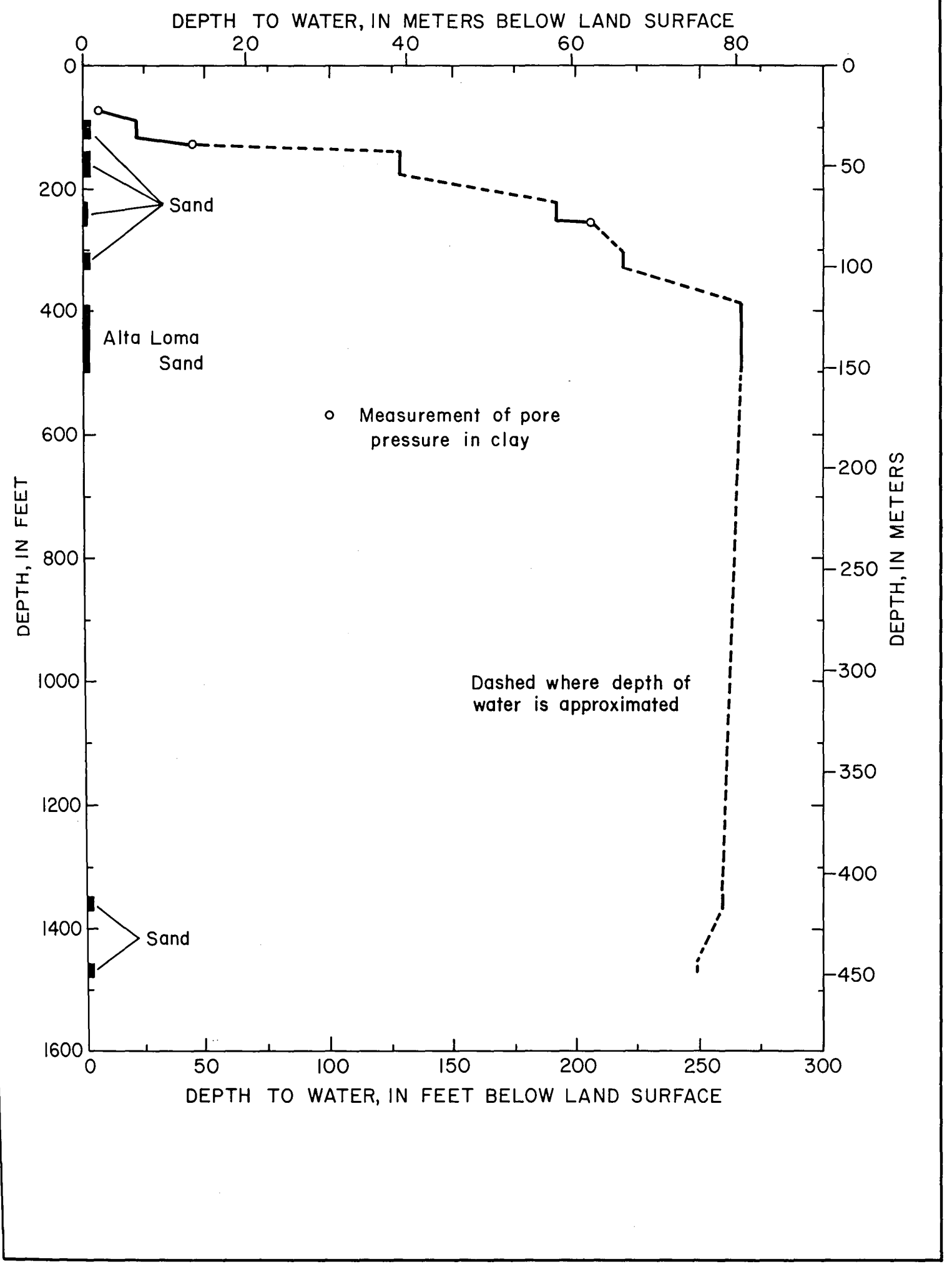

FIGURE 11.-Potentiometric profile at Baytown, March 1974 
The following assumptions were used to predict the rate of subsidence and the maximum amount of subsidence:

1. The altitude of the potentiometric surface in 1920 was the same as the original surface in 1890, and no subsidence occurred before 1920 .

2. Artesian-head declines in the Alta Loma Sand and Evangeline aquifer will continue at a rate of 6 feet $(1.8$ meters) per year until 1980. Thereafter, no further head declines will occur (case I).

3. Artesian-head declines in the A1ta Loma Sand will continue at a rate of 6 feet ( 1.8 meters) per year until 1980 and at a constant rate (approximately 6 feet or 1.8 meters per year) until the potentiometric surface reaches the top of the Alta Loma Sand in 1995. Thereafter, no further head declines will occur, and artesian heads in the Evangeline aquifer will continue to decline at a rate of 6 feet (1.8 meters) per year from 1970 to 1995 and then cease (case II).

\section{PREDICTED SUBSIDENCE}

The principal results of this study are given in the two graphs, figures 12 and 13. Figure 12 shows the calculated subsidence for 1920-75. For comparison, figure 12 includes a curve of the altitude of bench mark PTS 185 beginning in 1915. The computed values for a long period of time and under several different loading conditions correlate reasonably well with the measured changes in the altitude of the bench mark. However, the computed values for the 1920-73 period are subject to error. It should be expected that the samples tested should exhibit recompression for loads up to approximately the 1973 pressure. But in most instances, the samples exhibited virgin compression in the range of pressure analyzed.

The ultimate amount of subsidence was calculated, on the basis of current loading, to be 9.6 feet (2.93 meters). That is, if artesian heads were maintained at their present levels, it could be expected that about 1.4 feet ( 0.43 meter) of subsidence would occur in addition to the 8.2 feet (2.50 meters) that has already occurred.

The time it would take for 90 percent of the compaction leading to subsidence to occur ranges from about 14 days for a shallow clay layer about 2 feet ( 0.6 meter) thick to about 1,840 years for a deep clay layer about 100 feet (30 meters) thick. Many of the clay layers in the Baytown area are about 10-15 feet (3.05-4.57 meters) thick. For an assumed coefficient of consolidation of 10 square feet (0.93 square meter) per year and a bed thickness of 15 feet ( 4.6 meters), it would take 5 years to reach 90 percent consolidation.

The difference between calculated subsidence and measured subsidence in 1973 was 0.2 foot ( 0.06 meter). This difference is 2.4 percent of the total 8.2 feet (2.5 meters) that has occurred. Between 1950 and 1965, the calculated values of subsidence far exceeded the measured values. The maximum difference, which occurred in 1958, was 1.2 feet (0.37 meter) . 


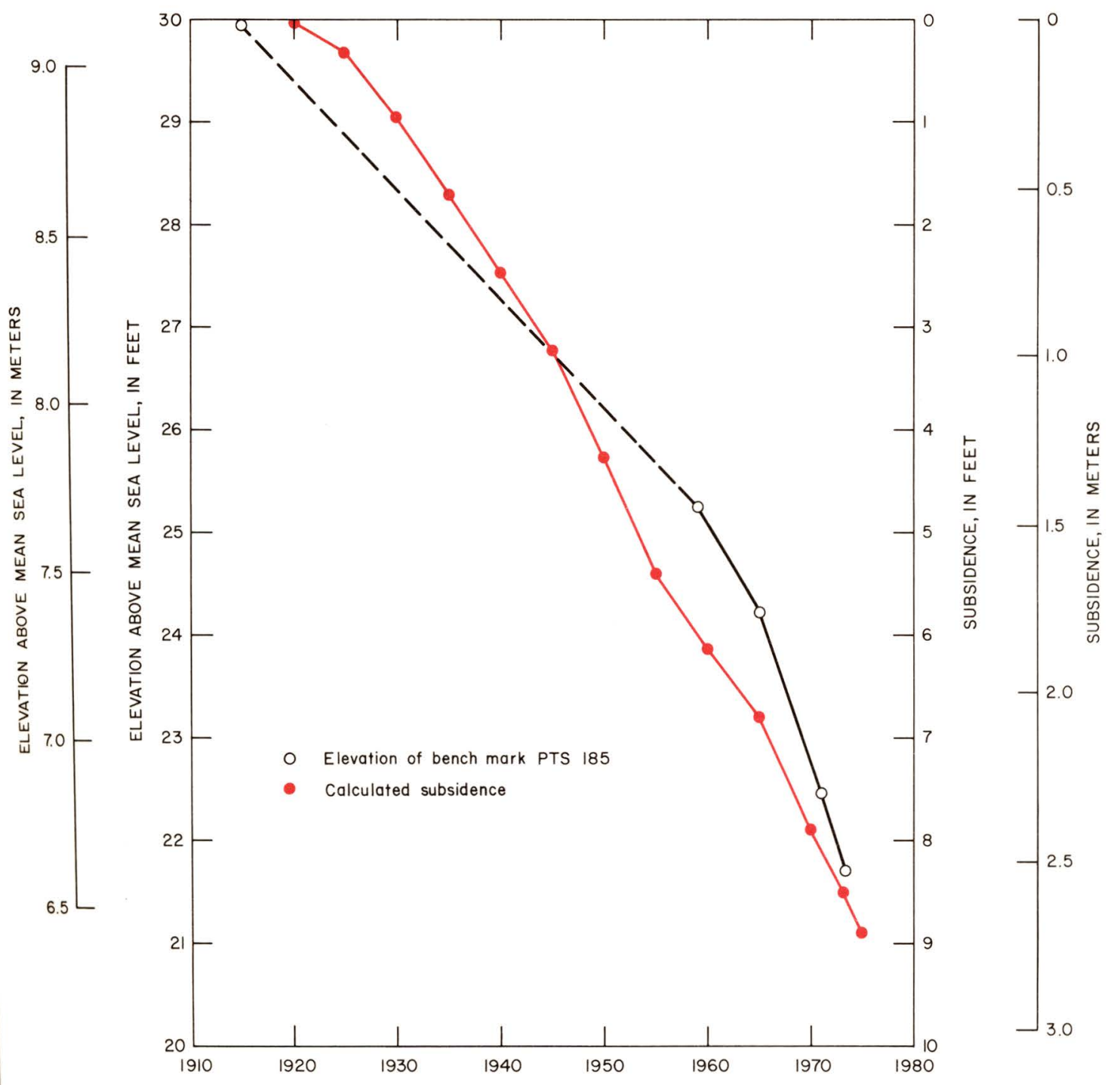




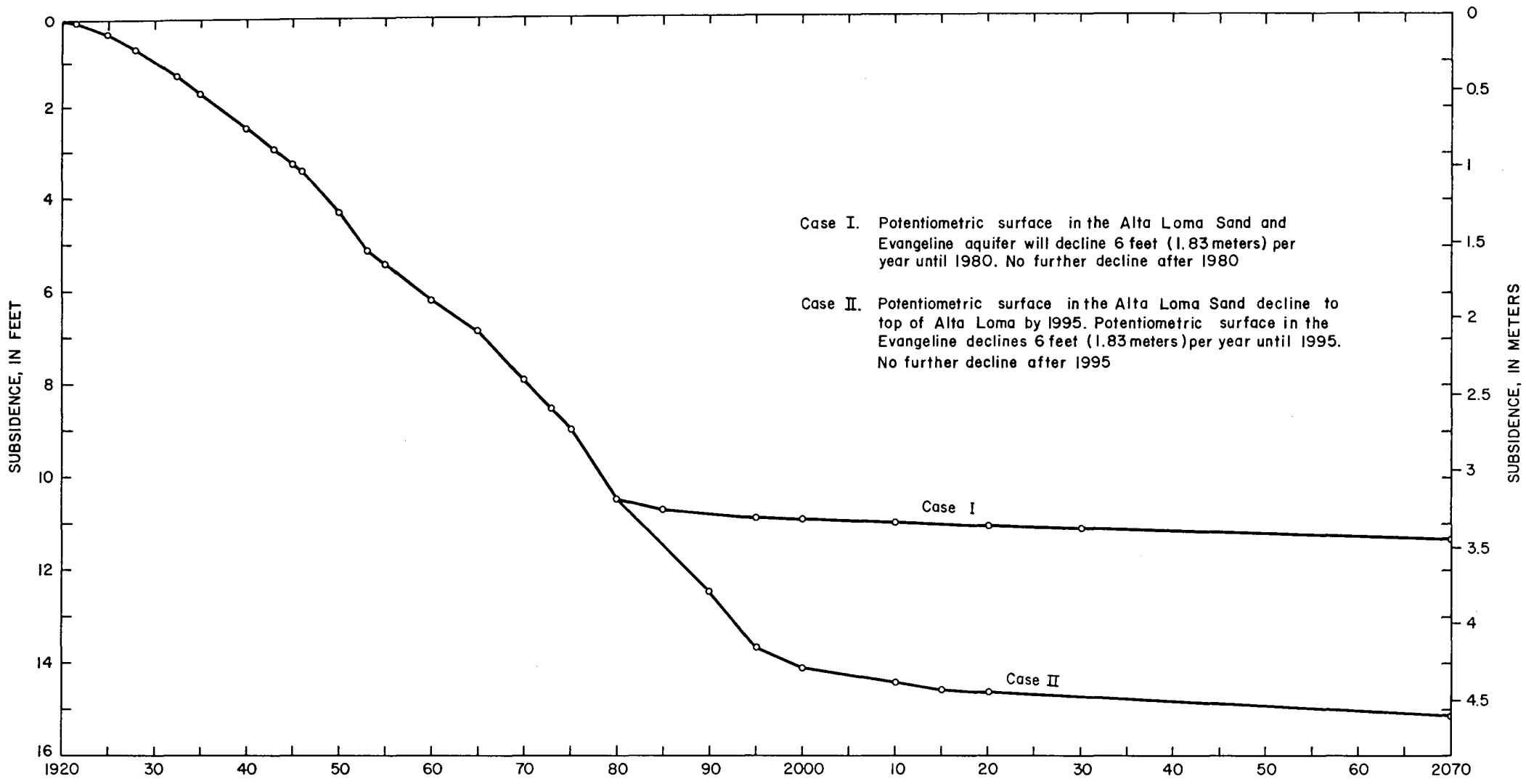

FIGURE 13.-Calculated land-surface subsidence in the area of Burnett, Scott, and Crystal Bays, 1920-2070 
Estimates of changes in hydraulic pressure within the compacting interval are critical to calculations of subsidence, because errors in calculated subsidence are directly related to errors in estimating changes in pressure. The estimates of changes in pressure with depth and time are probably better before 1950 and after 1965 than during 1950-65.

The rates of pressure decline and subsidence prior to 1950 were relatively small compared to the rates since 1950 , and because additional data are available, pressure declines are better defined after 1965 . Close correlation between calculated and measured subsidence before 1950 and after 1965 support the validity of the method of estimation.

These comparisons indicate that the assumptions, data translations, and interpretations are valid and may be used for predicting the rate and amount of subsidence that will occur in the future.

Figure 13 shows the subsidence calculated on the basis of estimated loading for 1920-73 and the subsidence calculated on the basis of two cases of assumed loading for 1980-2070. To obtain the loading under case I, it was assumed that by 1980, surface water would replace a part of the ground water being pumped in the Baytown and Pasadena areas. The decrease in ground-water pumping would be sufficient to halt further declines in water levels.

Commitments to purchase as much as $166 \mathrm{mgd}\left(7.27 \mathrm{~m}^{3} / \mathrm{s}\right)$ of water from Lake Livingston about 60 miles (97 kilometers) north of the study area in 1975 have been received from industrial representatives in the Pasadena area and areas south and east of Pasadena. If these commitments are met, ground-water withdrawals will decrease by 90 percent and case $I$ is a likely situation. However, if these commitments are not met, then case II is a likely situation.

The total amount of subsidence that could be expected if further artesian-head declines ceased in 1980 (case I) is 11.4 feet (3.47 meters). The total amount of subsidence that could be expected if artesian heads continue to decline at the rate of about 6 feet ( 1.8 meters) per year until 1995 (case II) is 15.1 feet ( 4.6 meters).

\section{CORRECTIVE MEASURES}

Subsidence of the land surface in the Baytown area will continue until pore pressures in the clays reach equilibrium with the pressure in the adjacent sands. Therefore, even if artesian pressure is maintained at the present (1973) level, compaction of the clay layers would continue for some time, but at a decreasing rate. 
According to measurements made in the clay layer at a depth of 344 feet ( 104.9 meters) at the monitoring site, the Alta Loma Sand would have to be repressured about $58 \mathrm{psi}\left(4.08 \mathrm{~kg} / \mathrm{cm}^{2}\right)$ to arrest the compaction. This increase in pressure is equal to raising the artesian head about 135 feet (41.1 meters). The clay layers at 71,126 , and 259 feet $(21.6,38.4$, and 78.9 meters) indicate excess pore pressure of 0,42 , and 8 feet $(0$, 12.8 , and 2.4 meters) of water, respectively. To halt compaction in the near future, the artesian pressure in the sands must be raised to a value equal to the pore pressure in the adjacent clay beds.

Two methods of repressurizing are: (1) Decreasing the rate of groundwater pumping in the area; and (2) artificial recharge of the aquifer. Artificial recharge would require that the injected water be of a quality suitable for future use and be compatible with the native ground water and associated water-bearing material. These requirements would probably require treatment of any available surface water.

Although at least a dozen wells drilled for the disposal of liquid wastes are in operation in Harris and surrounding counties, no largescale fresh-water injection is underway or planned. Additional fresh water is available to Harris County from both ground-water resources and nearby lakes. A decrease in pumpage would cause artesian pressures to increase by natural means and is probably the most logical solution to the problem of artesian-head declines and land-surface subsidence.

Experience in other areas, notably in California, where the hydrology and clay mineralogy are similar to that of the Texas Gulf Coast region, demonstrates that recovery of the land surface by repressurizing would probably be less than 5 percent of subsidence.

According to Allen and Mayuga (1969, p. 418), repressurizing of the oil field at Wilmington, California, caused as much as 1.1 feet $(0.34$ meter) of land-surface rise by 1968. However, at the center of the subsidence bowl, about 1 foot ( 0.3 meter) of land-surface rise had been experienced by 1968 (fig. 14, p. 421), and Allen and Mayuga estimated a maximum additional rebound of 2.0 to 2.5 feet ( 0.61 to 0.76 meter). The rebound that had occurred was about 3 percent of subsidence, and the total rebound expected was about 12 percent of the 30.4 feet ( 9.3 meters) of subsidence. Unlike the Baytown area, subsidence at Wilmington is attributed principally to compaction of the sands rather than the shales. Allen and Mayuga further state (p. 419) that rebound generated in the shales is insignificant. 
Table 1.--Physical properties of clay samples

\begin{tabular}{crrcccc}
\hline $\begin{array}{l}\text { Sample } \\
\text { no. I/ }\end{array}$ & $\begin{array}{r}\text { Sample } \\
\text { depth } \\
\text { (feet) }\end{array}$ & $\begin{array}{c}\text { Specific } \\
\text { gravity }\end{array}$ & $\begin{array}{c}\text { Water } \\
\text { content } \\
\text { (percent) }\end{array}$ & $\begin{array}{c}\text { Liquid } \\
\text { limit } \\
\text { (percent) }\end{array}$ & $\begin{array}{c}\text { P1astic } \\
\text { limit } \\
\text { (percent) }\end{array}$ & $\begin{array}{c}\text { P1asticity } \\
\text { index }\end{array}$ \\
\hline 1 & 141 & 2.27 & -- & 48 & 28 & 20 \\
2 & 211 & 2.60 & a/ 29.2 & 33 & 17 & 16 \\
3 & 265 & 2.64 & a/ 33.6 & 41 & 17 & 24 \\
4 & 346 & 2.63 & a/ 34.6 & 52 & 22 & 30 \\
5 & 541 & 2.75 & b/ 26 & 54 & 30 & 24 \\
6 & 800 & 2.75 & b/ 26 & 48 & 18 & 30 \\
7 & 1,004 & 2.77 & b/ 18 & 45 & 20 & 25 \\
8 & 1,216 & 2.75 & b/ 18 & 45 & 20 & 15 \\
9 & 1,647 & 2.74 & b/ 47.3 & -- & - & -- \\
\hline
\end{tabular}

1/ Samples 1-4 tested by U.S. Geological Survey laboratory, Denver, Colorado; samples 5-8 tested by Texas A \& M University, College Station, Texas; and sample 9 collected at the University of Houston and tested by Lyle A. Wolfskill.

a/ Percent by volume.

b/ Percent by weight. 
Table 2.--Coefficients of consolidation and hydraulic conductivity of clay samples

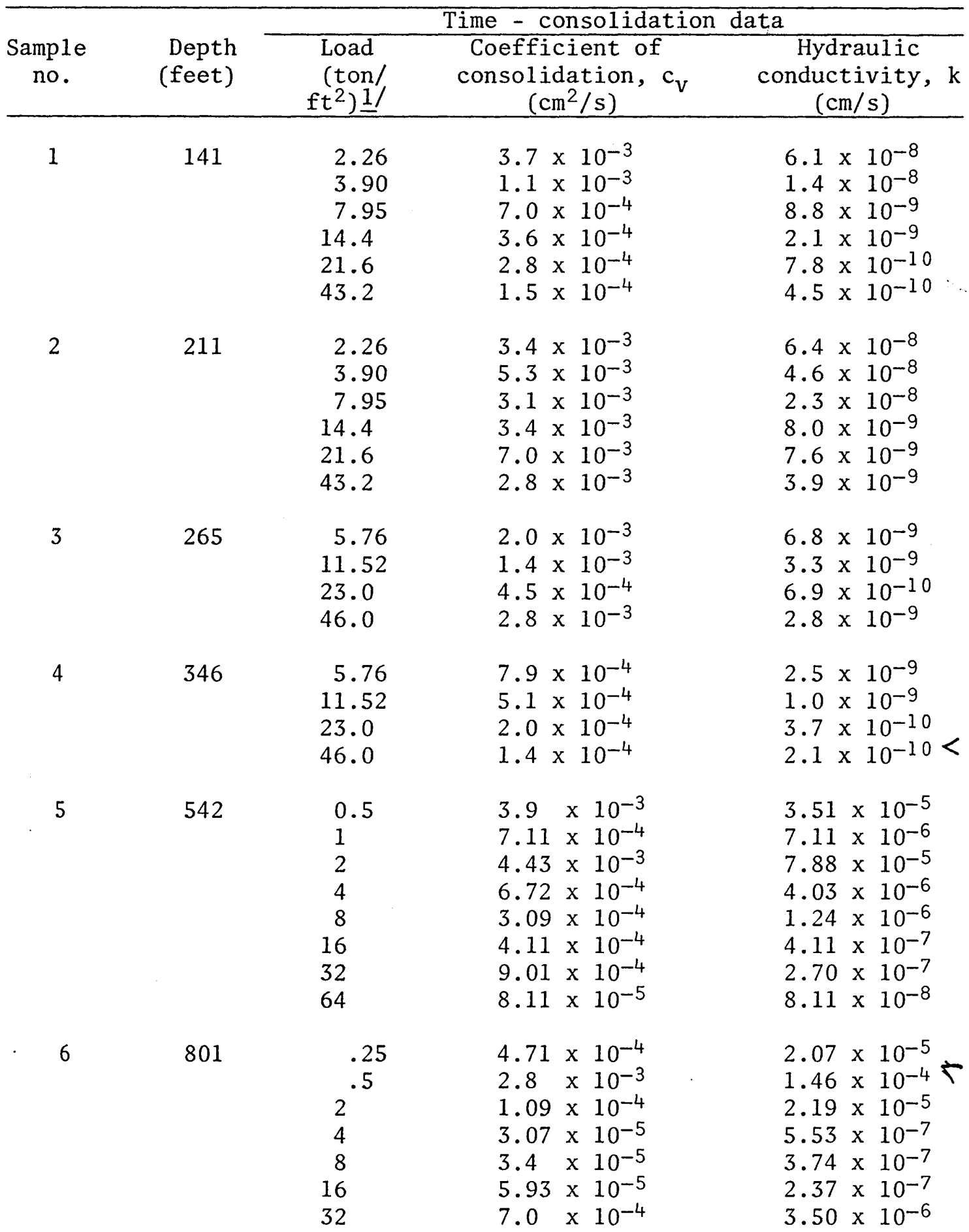


Table 2.--Coefficients of consolidation and hydraulic conductivity of clay samples--Continued

\begin{tabular}{|c|c|c|c|c|}
\hline \multirow[b]{2}{*}{$\begin{array}{c}\text { Sample } \\
\text { no. }\end{array}$} & \multirow[b]{2}{*}{$\begin{array}{c}\text { Depth } \\
\text { (feet) }\end{array}$} & \multicolumn{3}{|c|}{ Time - consolidation data } \\
\hline & & $\begin{array}{l}\text { Load } \\
\text { (ton// } \\
\left.f t^{2}\right) 1 /\end{array}$ & $\begin{array}{c}\text { Coefficient of } \\
\text { consolidation, } \mathrm{c}_{\mathrm{v}} \\
\left(\mathrm{cm}^{2} / \mathrm{s}\right)\end{array}$ & $\begin{array}{c}\text { Hydraulic } \\
\text { conductivity, } \mathrm{k} \\
(\mathrm{cm} / \mathrm{s})\end{array}$ \\
\hline 7 & 1,004 & $\begin{array}{r}2 \\
4 \\
8 \\
16 \\
32 \\
64 \\
128\end{array}$ & $\begin{array}{l}1.56 \times 10^{-2} \\
7.6 \times 10^{-3} \\
1.48 \times 10^{-4} \\
5.16 \times 10^{-3} \\
8.96 \times 10^{-4} \\
5.29 \times 10^{-4} \\
1.81 \times 10^{-4}\end{array}$ & $\begin{array}{l}1.25 \times 10^{-4} \\
4.1 \times 10^{-5} \\
3.99 \times 10^{-7} \\
1.08 \times 10^{-5} \\
6.27 \times 10^{-7} \\
3.70 \times 10^{-7} \\
3.62 \times 10^{-8}\end{array}$ \\
\hline 8 & 1,216 & $\begin{array}{l}1 \\
1.7 \\
4 \\
8 \\
16 \\
32 \\
64 \\
128 \\
256\end{array}$ & $\begin{array}{l}6.22 \times 10^{-3} \\
9.10 \times 10^{-3} \\
3.85 \times 10^{-3} \\
3.44 \times 10^{-3} \\
3.17 \times 10^{-3} \\
1.85 \times 10^{-3} \\
1.62 \times 10^{-3} \\
9.10 \times 10^{-4} \\
7.56 \times 10^{-4}\end{array}$ & $\begin{array}{l}7.95 \times 10^{-8} \\
8.19 \times 10^{-8} \\
2.19 \times 10^{-8} \\
1.72 \times 10^{-8} \\
8.24 \times 10^{-9} \\
3.34 \times 10^{-9} \\
2.59 \times 10^{-9} \\
1.18 \times 10^{-9} \\
6.50 \times 10^{-10}\end{array}$ \\
\hline 9 & 1,647 & 128 & $1.34 \times 10^{-5}$ & -- \\
\hline
\end{tabular}


Table 3.--Thickness of clay and maximum clay-bed thickness

\begin{tabular}{cccc}
\hline $\begin{array}{c}\text { Layer } \\
\text { number }\end{array}$ & $\begin{array}{c}\text { Depth } \\
\text { interval } \\
\text { (feet) }\end{array}$ & $\begin{array}{c}\text { Clay } \\
\text { thickness } \\
(\text { feet })\end{array}$ & $\begin{array}{c}\text { Maximum } \\
\text { clay-bed } \\
\text { thickness } \\
(\text { feet })\end{array}$ \\
\hline
\end{tabular}

1

31-42

11

4

2

52-84

32

4

84-116

3

2

116-142

23

4

$142-182$

4

2

197-213

12

4

224-228

4

4

234-250

12

2

254-272

16

4

10

$298-300$

2

2

11

$300-328$

6

2

328-365

37

30

13

$370-390$

20

12

14

$500-522$

10

4

15

532-536

4

4

16

536-553

17

17

17

556-558

2

2

18

$570-580$

10

10

19

585-610

15

5

20

617-630

13

13

21

650-654

4

4

22

657-664 
Table 3.--Thickness of clay and maximum clay-bed thickness--Continued

\begin{tabular}{cccc}
\hline $\begin{array}{c}\text { Layer } \\
\text { number }\end{array}$ & $\begin{array}{c}\text { Depth } \\
\text { interval } \\
(\text { feet })\end{array}$ & $\begin{array}{c}\text { Clay } \\
\text { thickness } \\
(\text { feet })\end{array}$ & $\begin{array}{c}\text { Maximum } \\
\text { clay-bed } \\
\text { thickness } \\
\text { (feet) }\end{array}$ \\
\hline
\end{tabular}

23

$672-676$

4

4

24

$727-733$

6

6

25

$756-763$

5

5

26

767-772

5

5

27

$780-782$

2

2

28

788-795

7

7

798-817

19

19

30

$820-824$

4

4

$826-828$

2

2

834-853

19

8

33

892-894

2

2

34

897-903

6

6

35

913-920

5

5

36

933-935

2

2

37

956-964

8

8

38

973-974

1

1

39

979-981

2

2

40

986-1014

28

8

41

1113-1161

48

10

42

1190-1239

49

49

43

$1265-1273$

8

8

44

$1300-1304$

4 
Table 3.--Thickness of clay and maximum clay-bed thickness--Continued

\begin{tabular}{cccc}
\hline $\begin{array}{c}\text { Layer } \\
\text { number }\end{array}$ & $\begin{array}{c}\text { Depth } \\
\text { interval } \\
(\text { feet })\end{array}$ & $\begin{array}{c}\text { Clay } \\
\text { thickness } \\
\text { (feet) }\end{array}$ & $\begin{array}{c}\text { Maximum } \\
\text { clay-beds } \\
\text { thickness } \\
\text { (feet) }\end{array}$ \\
\hline
\end{tabular}

45

1311-1313 
Table 3.--Thickness of clay and maximum clay-bed thickness--Continued

\begin{tabular}{|c|c|c|c|}
\hline $\begin{array}{r}\text { Layer } \\
\text { number }\end{array}$ & $\begin{array}{c}\text { Depth } \\
\text { interval } \\
\text { (feet) }\end{array}$ & $\begin{array}{c}\text { Clay } \\
\text { thickness } \\
\text { (feet) }\end{array}$ & $\begin{array}{c}\text { Maximum } \\
\text { clay-beds } \\
\text { thickness } \\
\text { (feet) }\end{array}$ \\
\hline 67 & $2395-2424$ & 25 & 25 \\
\hline 68 & $2430-2455$ & 18 & 10 \\
\hline
\end{tabular}


Allen, D. R., and Mayuga, M. N., 1969, The mechanics of compaction and rebound, Wilmington Oil Field, Long Beach, California, U.S.A.: Internat. symposium of land subsidence, Tokyo, Japan, 1969, Proc., p. 410-422.

Gabrysch, R. K., 1969, Land-surface subsidence in the Houston-Galveston region, Texas: Internat. symposium on land subsidence, Tokyo, Japan, 1969, Proc., p. 43-54.

1971, Development of ground water in the Houston district, Texas, 1966-69: Texas Water Deve1. Board Rept. 152, 24 p.

1972, Preliminary report on land-surface subsidence in the area of Burnett, Scott, and Crystal Bays near Baytown, Texas: U.S. Geol. Survey open-file rept., 25 p.

Gabrysch, R. K., Bonnet, C. W., and Naftel, W. L., 1970, Records of waterlevel measurements in wells in Harris County, Texas, 1966-69: Texas Water Devel. Board Rept. 122, $67 \mathrm{p}$.

Gabrysch, R. K., Nafte1, W. L., and McAdoo, G. D., 1969, Records of waterlevel measurements in observation wells in Harris County, Texas:

Texas Water Deve1. Board Rept. 103, 252 p. Miller, R. E., 1961, Compaction of an aquifer system computed from consolidation tests and decline in artesian head: U.S. Geol. Survey Prof. Paper 424-B, p. 54-58.

Poland, J. F., 1969, Status of present knowledge and needs for additional research on compaction of aquifer systems: Internat. symposium on land subsidence, Tokyo, Japan, 1969, Proc., p. 11-21.

Poland, J. F., and Davis, G. H., 1969, Land subsidence due to the withdrawal of fluids: Reviews in Engineering Geology II, Geological Society of America, Inc., p. 187-269.

Pratt, W. E., and Johnson, D. W., 1926, Local subsidence of the Goose Creek Oil Field: The Journal of Geology, v. XXXIV, no. 7, pt. 1, p. 577-590.

Riley, F. S., 1969, Analysis of borehole extensiometer data from central California: Internat. symposium on land subsidence, Tokyo, Japan, 1969, Proc., p. 423-431.

Rose, N. A., 1943, Progress report on the ground-water resources of the Texas City area, Texas: Texas Board of Water Engineers, U.S. Geol. Survey open-file rept., 45 p., 3 figs.

Taylor, D. W., 1948, Fundamentals of soil mechanics: New York, John Wiley and Sons, Inc., 703 p.

Terazghi, Karl, and Peck, Ralph, 1948, Soil mechanics in engineering practice: New York, John Wiley and Sons, Inc., 566 p.

Winslow, A. G., and Doyel, W. W., 1954, Land-surface subsidence and its relation to the withdrawal of ground water in the Houston-Galveston region, Texas: Econ. Geol., v. 49, no. 4, p. 413-422.

Winslow, A. G., and Wood, L. A., 1959, Relation of land subsidence to ground-water withdrawals in the upper Gulf Coast region, Texas: Mining Engin., Oct., p. 1030-1034; Am. Inst. Mining, Meta11., Petroleum Engin., Trans., v. 214. 


\section{SELECTED REFERENCES--Continued}

Wolfski11, L. A., 1960, The consolidation characteristics of undisturbed soil samples of deep formations and their application to problems of regional subsidence: Master of Science Thesis, Texas A \& M University, College Station, $70 \mathrm{p}$.

Wood, L. A., and Gabrysch, R. K., 1965, An analog-model study of ground water in the Houston district, Texas, with a section on design, construction, and use of analog models, by E. P. Patten, Jr.: Texas Water Commission Bul1. 6508, 103 p. 


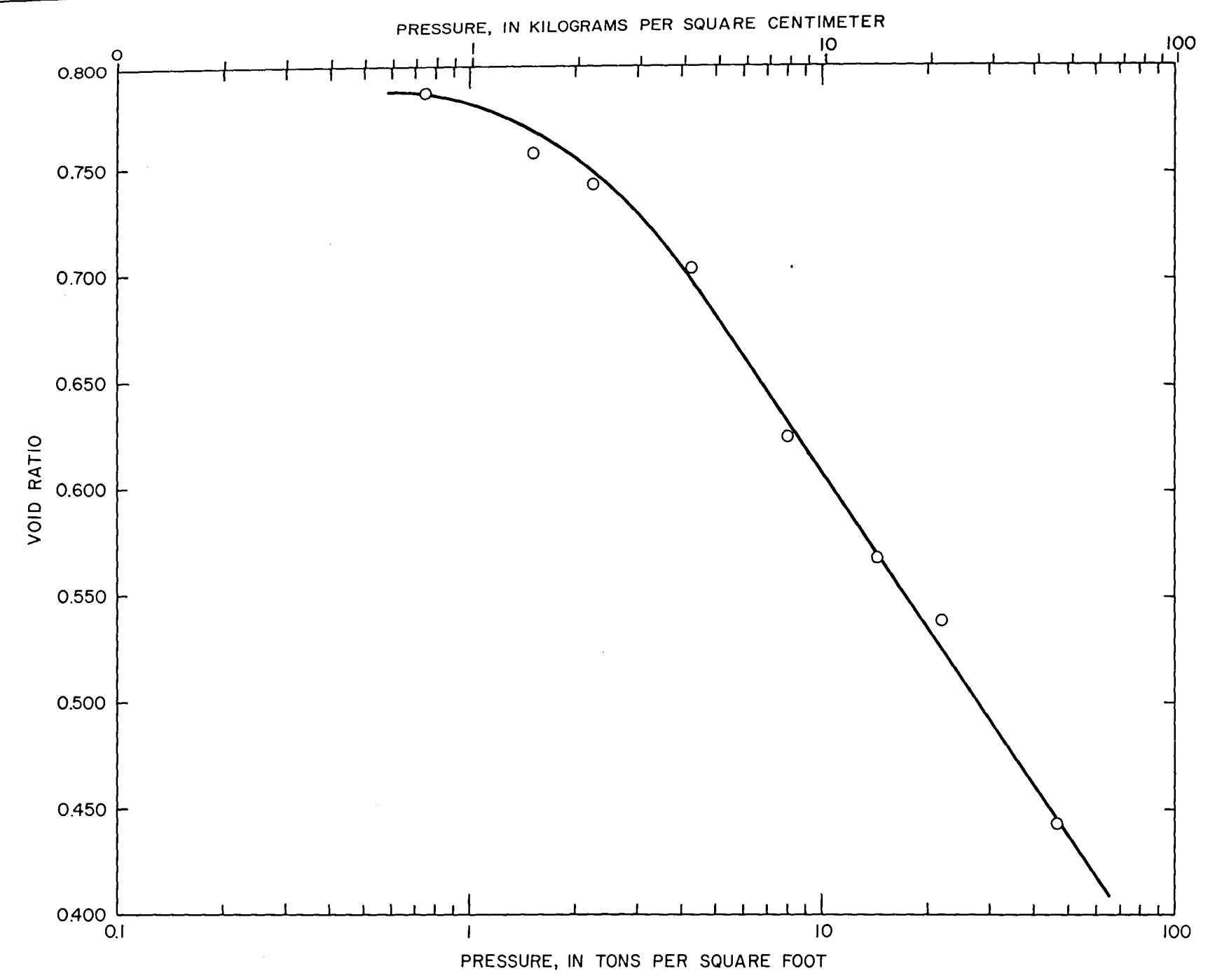

FIGURE 14.-Relation between void ratio and applied pressure for a clay sample from a depth of 141 feet (43 meters) 


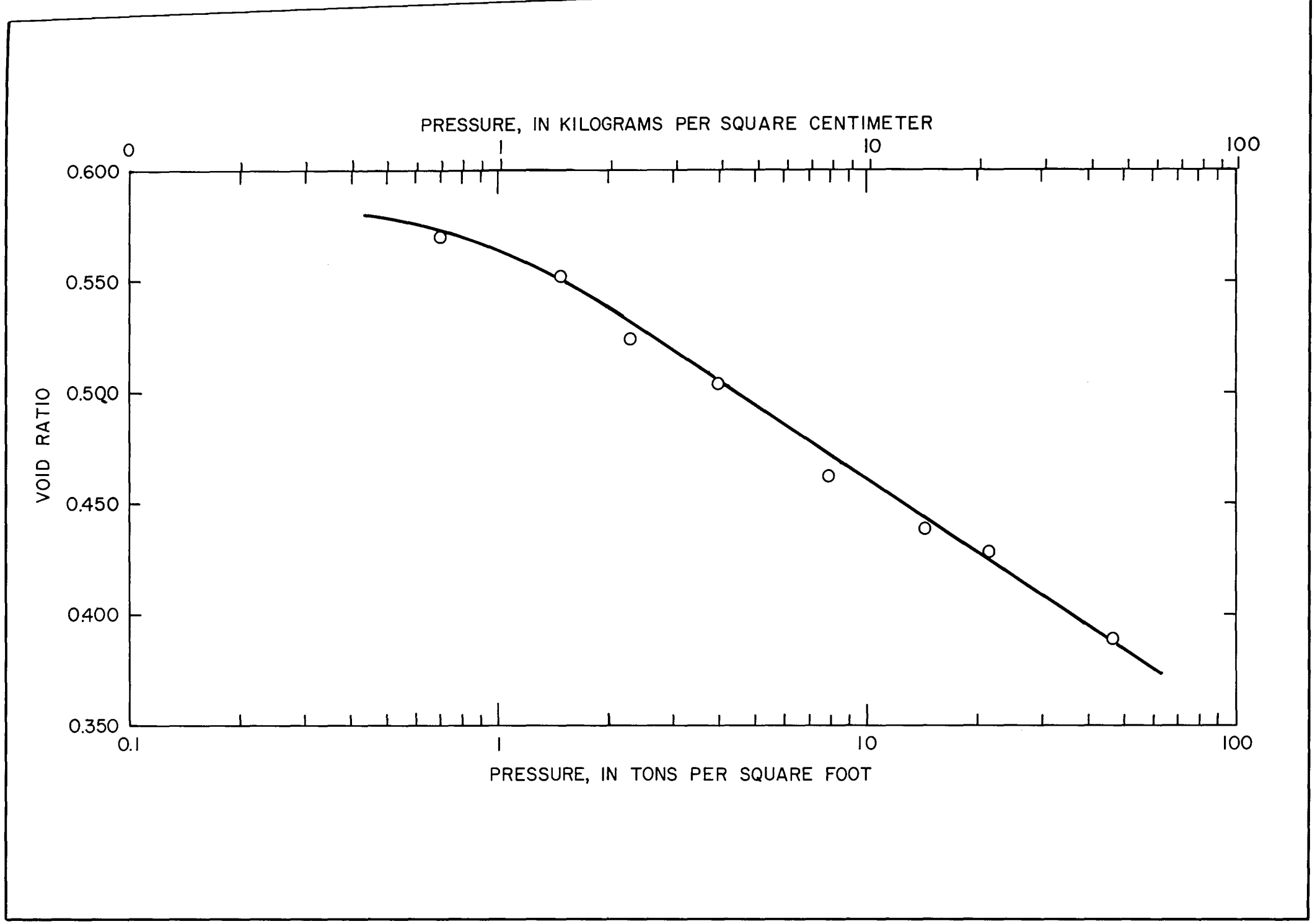

FIGURE 15.-Relation between void ratio and applied pressure for a clay sample from a depth of 211 feet $(64$ meters) 


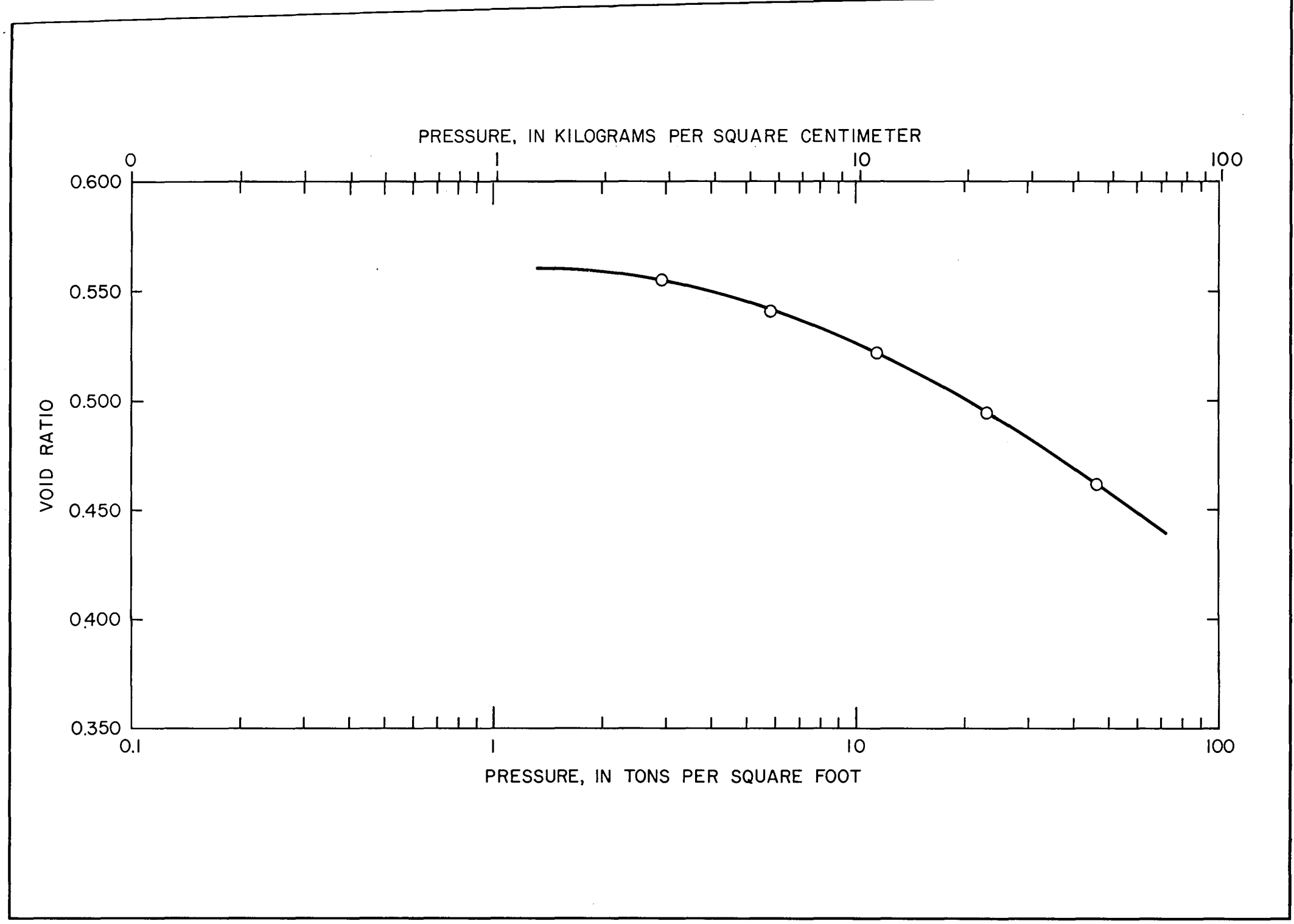

FIGURE 16.-Relation between void ratio and applied pressure for a clay sample from a depth of 265 feet (81 meters) 


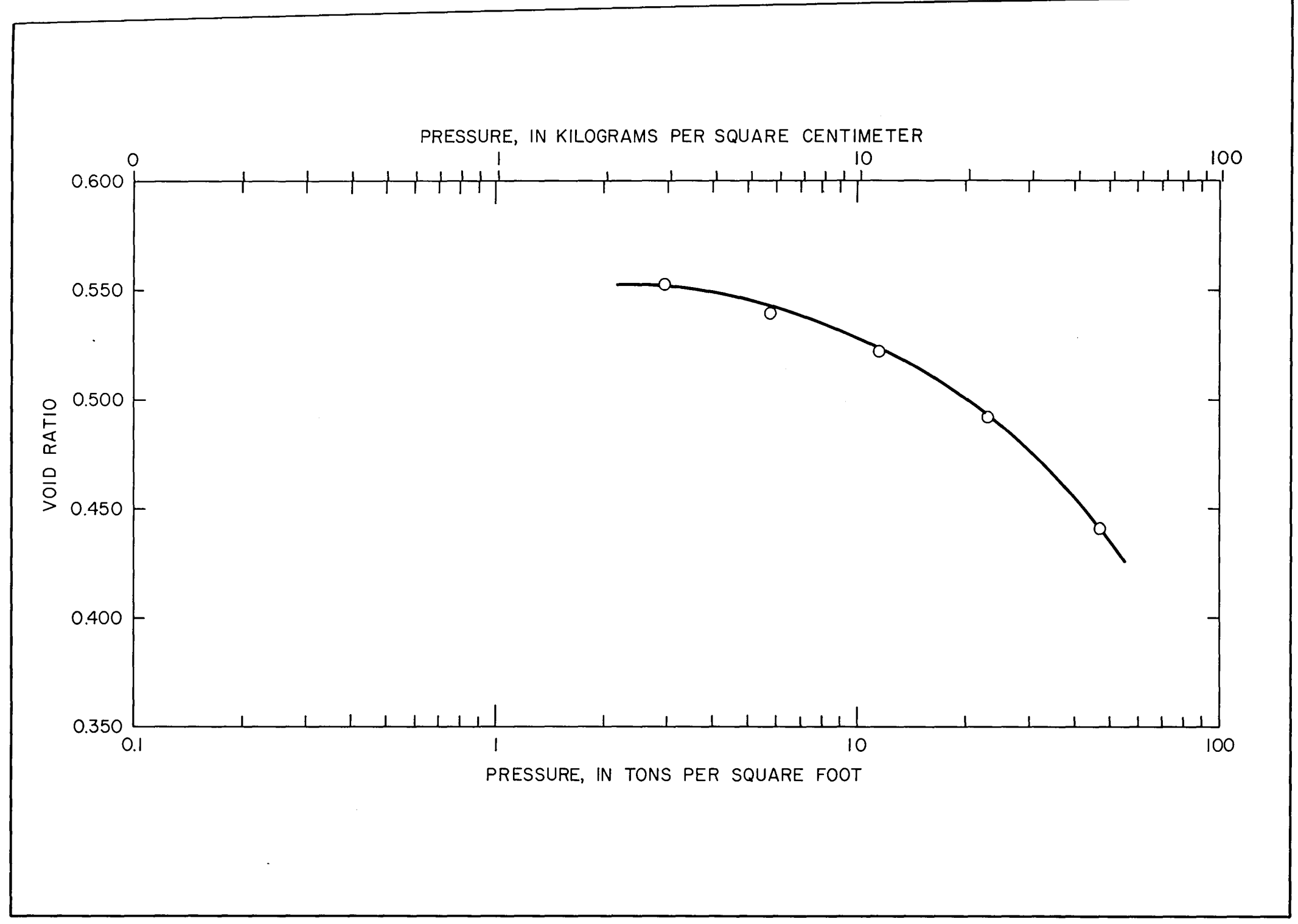

FIGURE 17 .-Relation between void ratio and applied pressure for a clay sample from a depth of 346 feet (105 meters) 


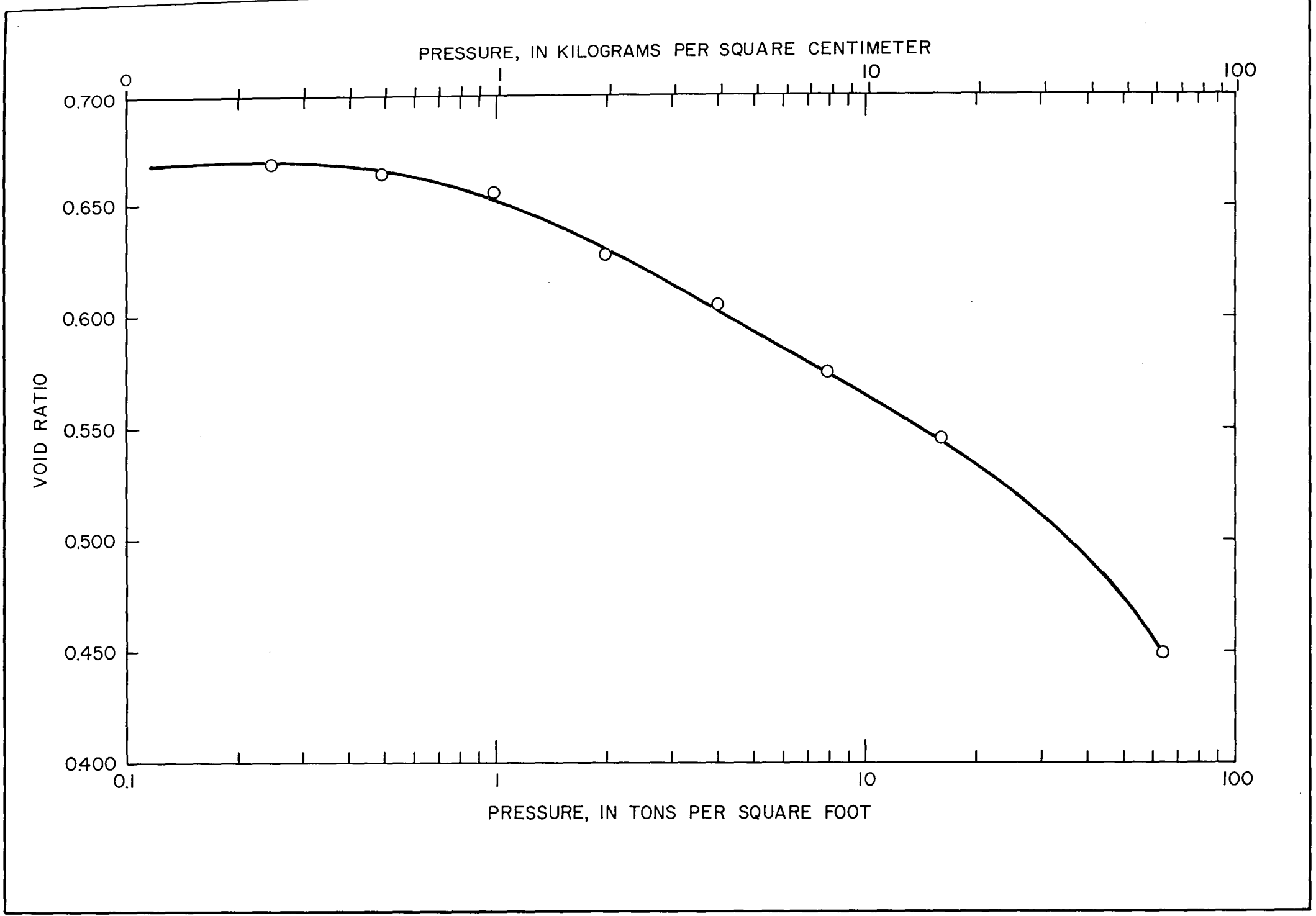

FIGURE 18.-Relation between void ratio and applied pressure for a clay sample from a depth of 541 feet (165 meters) 


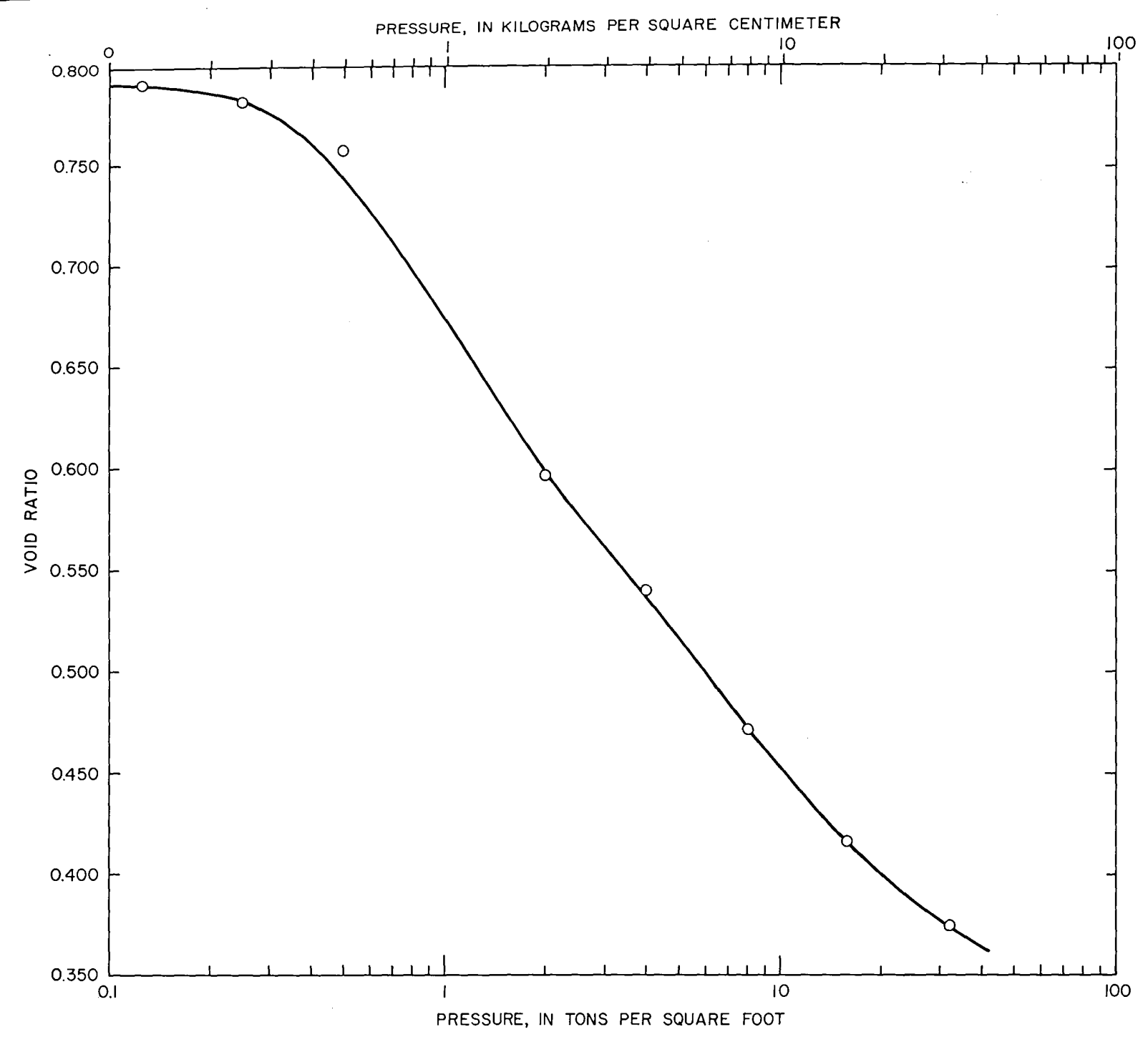

FIGURE 19.-Relation between void ratio and applied pressure for a clay sample from a depth of 800 feet (244 meters) 


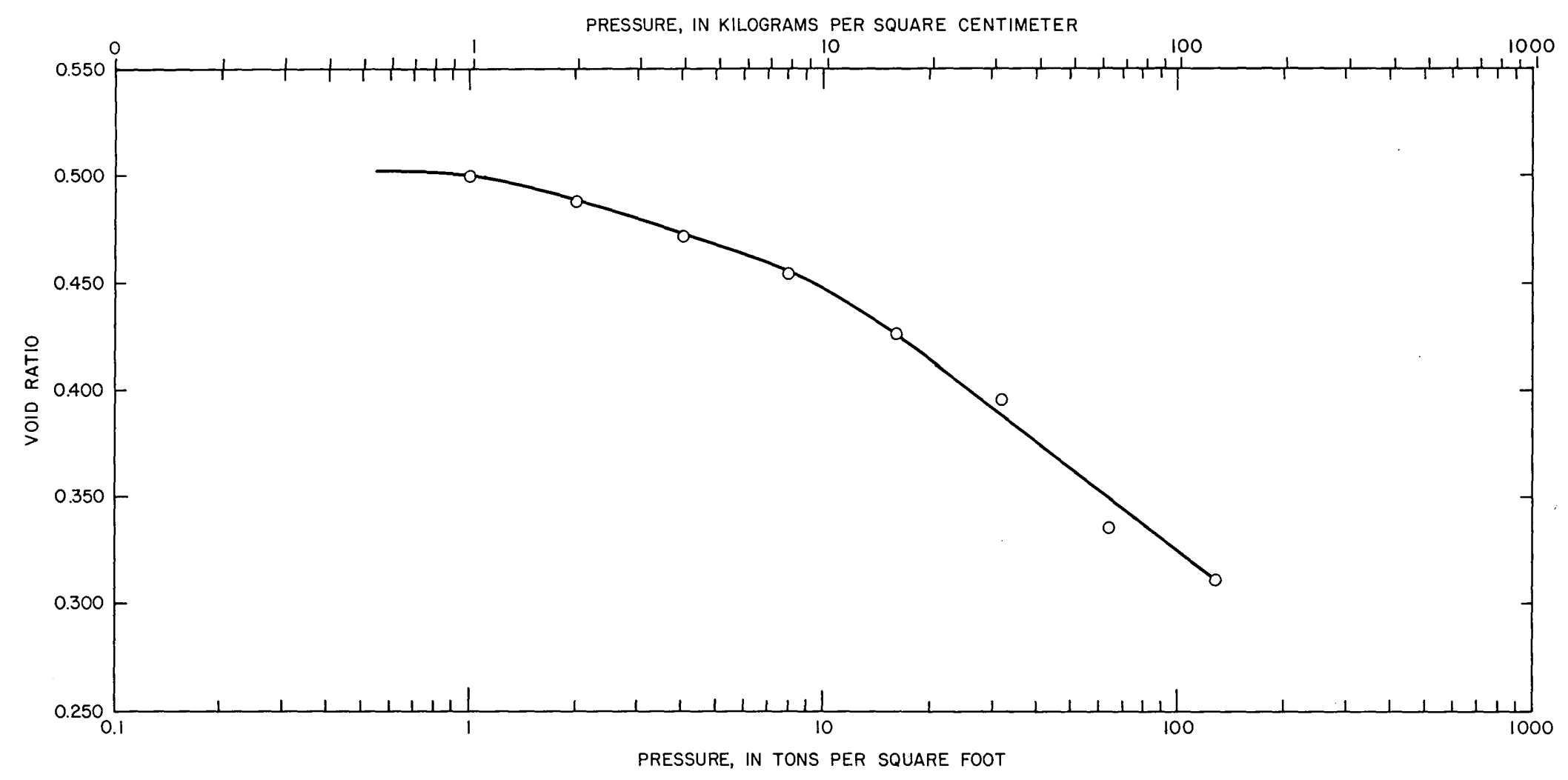




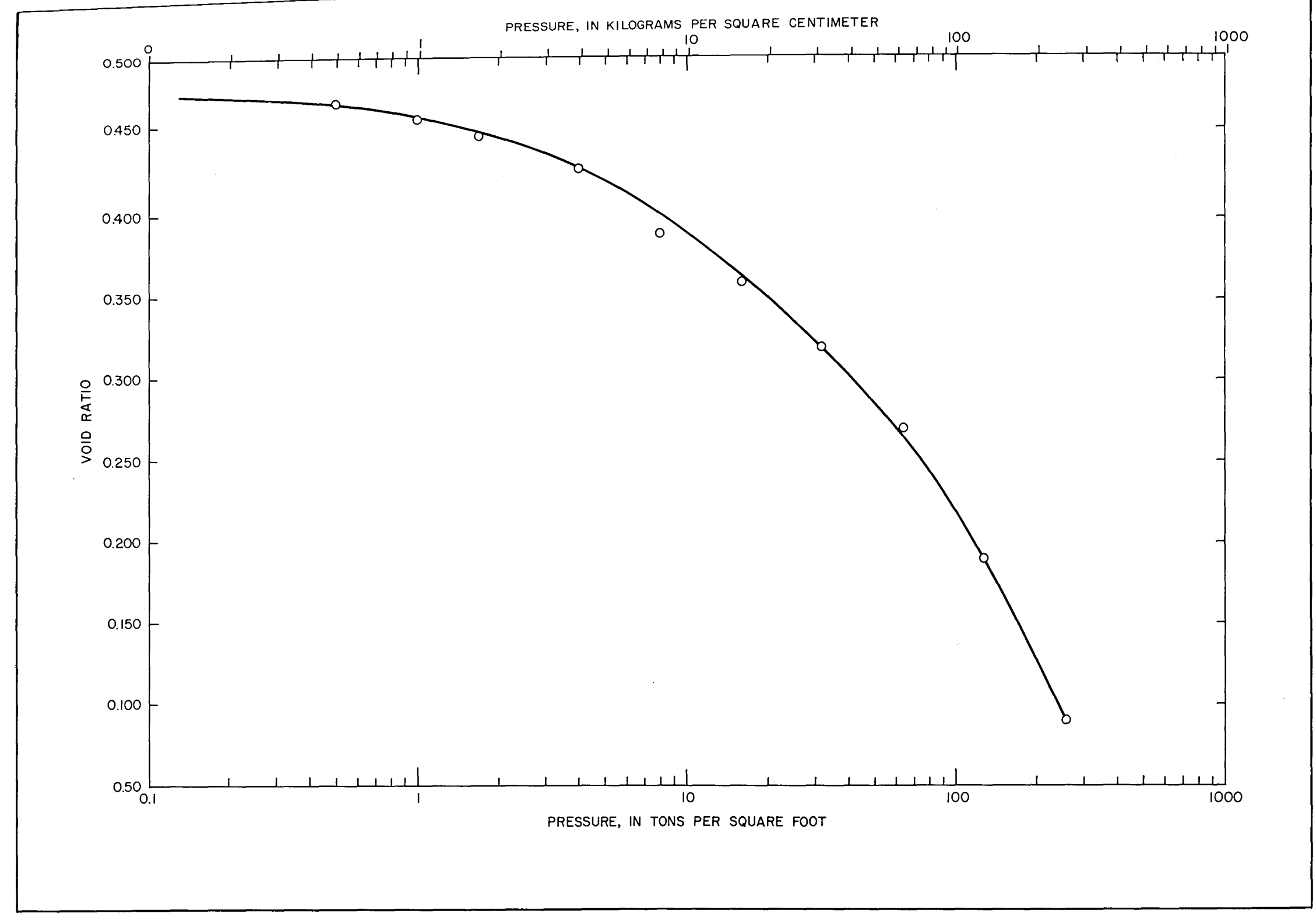

FIGURE 21.-Relation between void ratio and applied pressure for a clay sample from a depth of 1,216 feet (371

meters) 


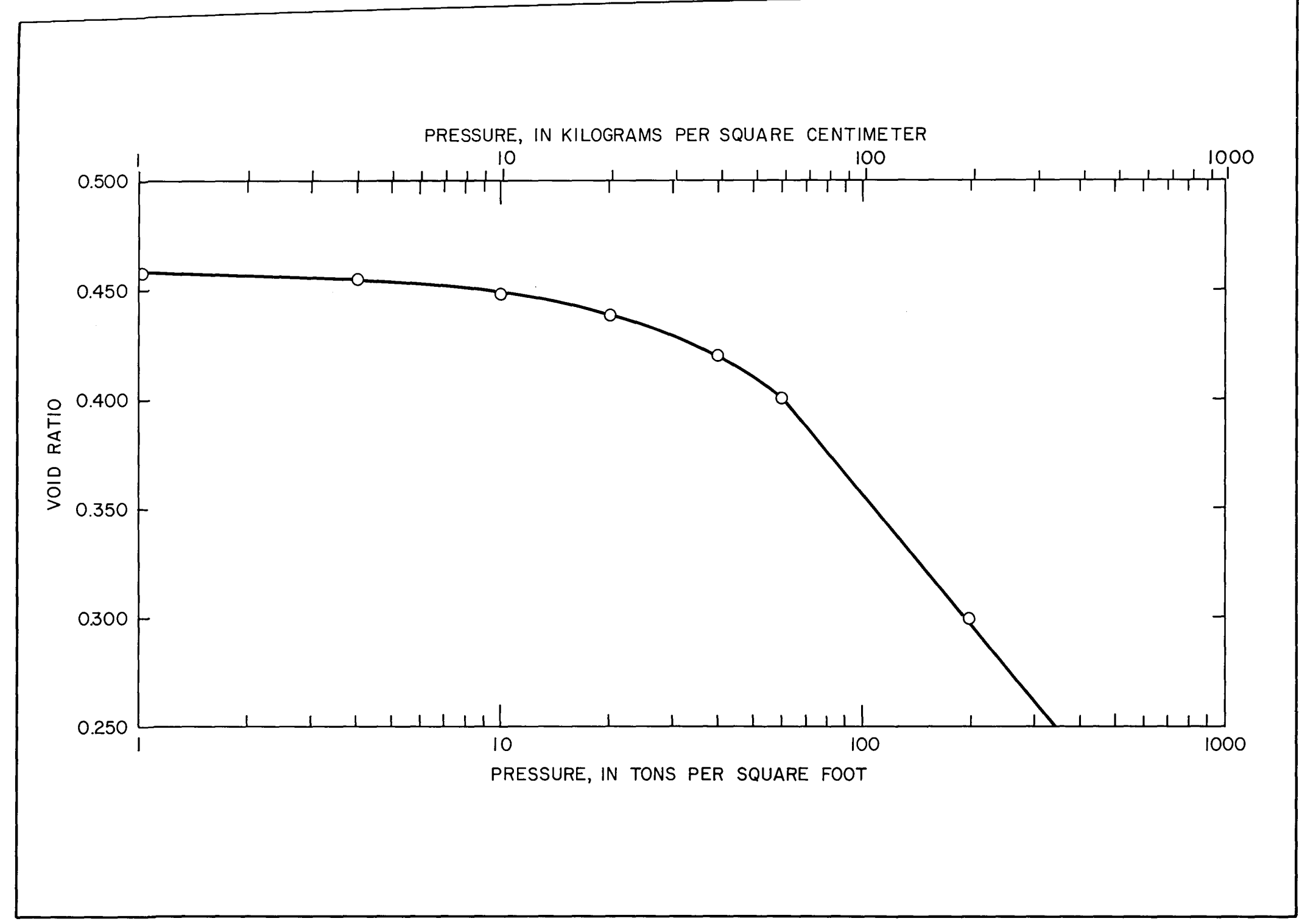

FIGURE 22.-Relation between void ratio and applied pressure for a clay sample from a depth of 1,647 feet (502 meters) 


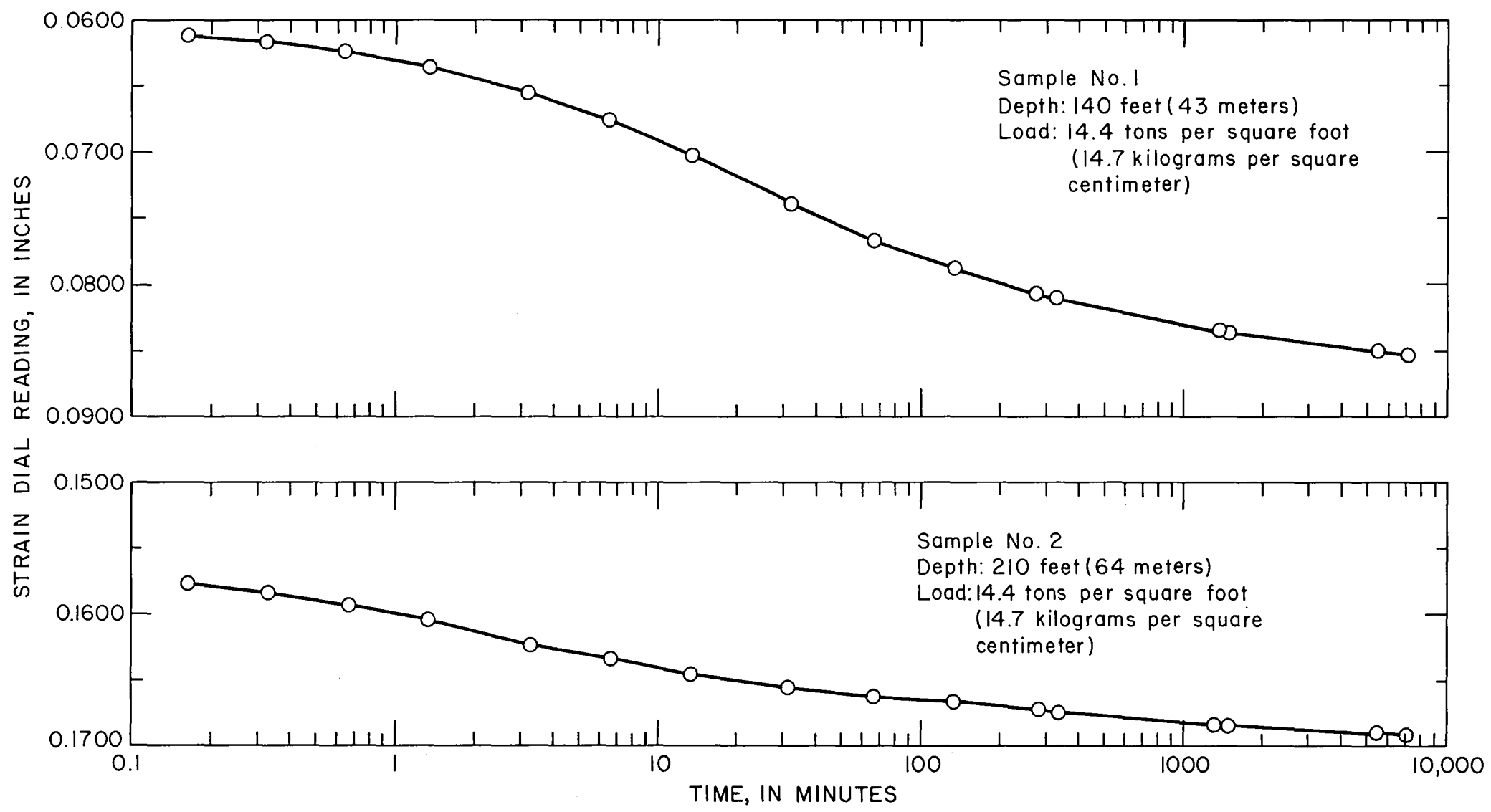

FIGURE 23.-Relation between consolidation and time for clay samples from depths of 140 and 210 feet (43 and 64 meters) 


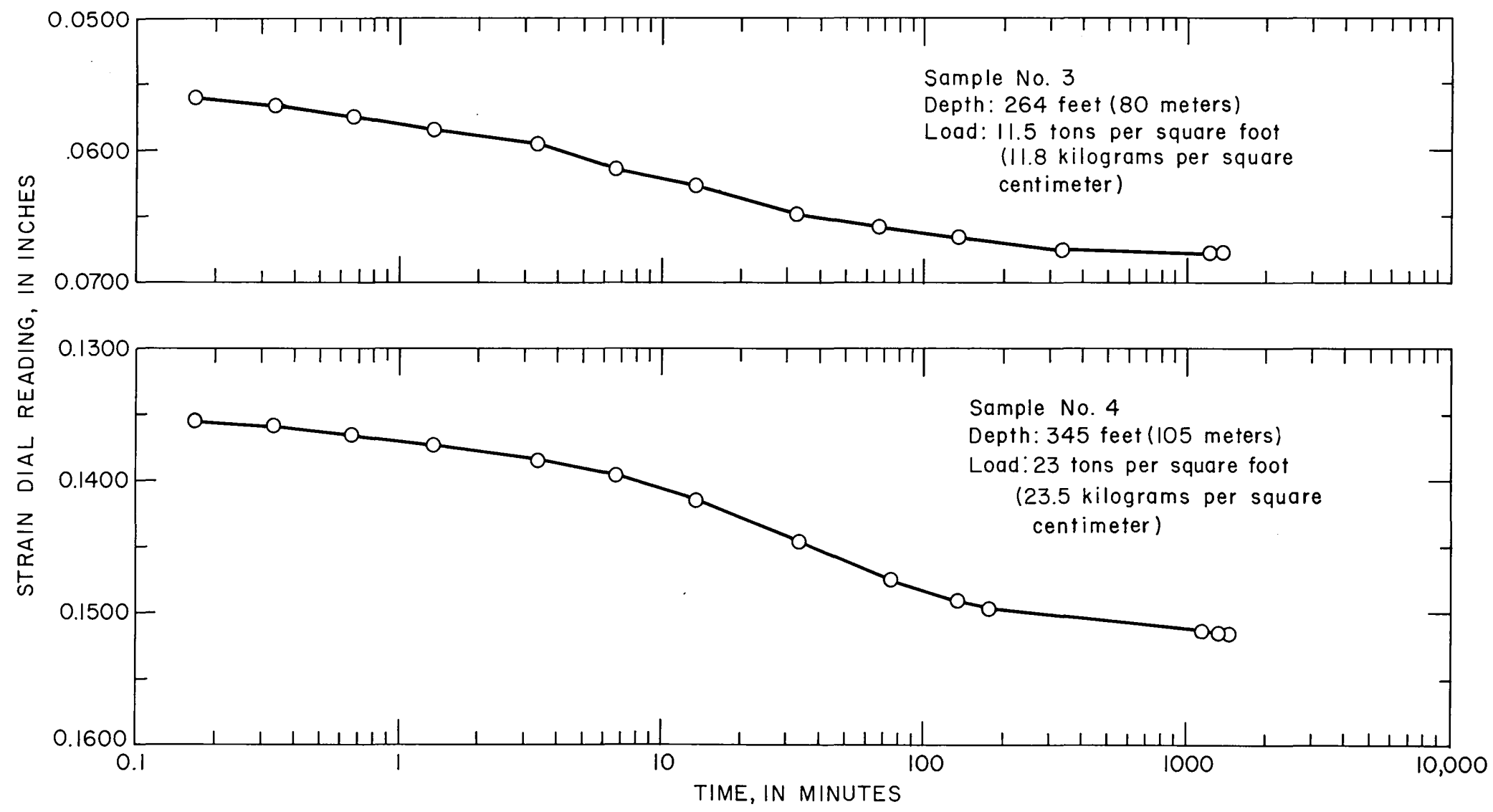

FIGURE 24.-Relation between consolidation and time for clay samples from depths of 264 and 345 feet (80 and 105 meters) 


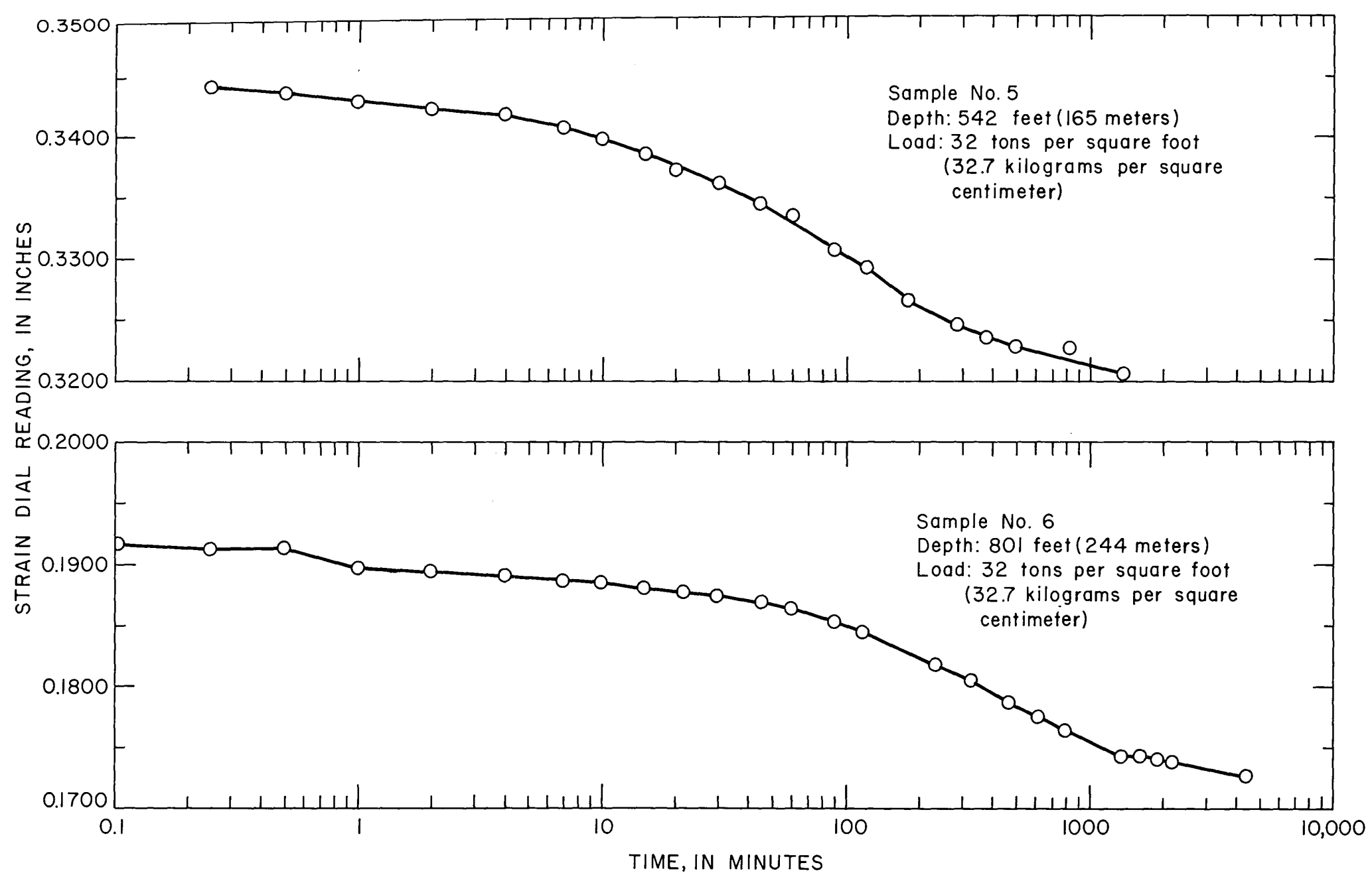

FIGURE 25.-Relation between consolidation and time for clay samples from depths of 542 and 801 feet (165 and 244 meters) 


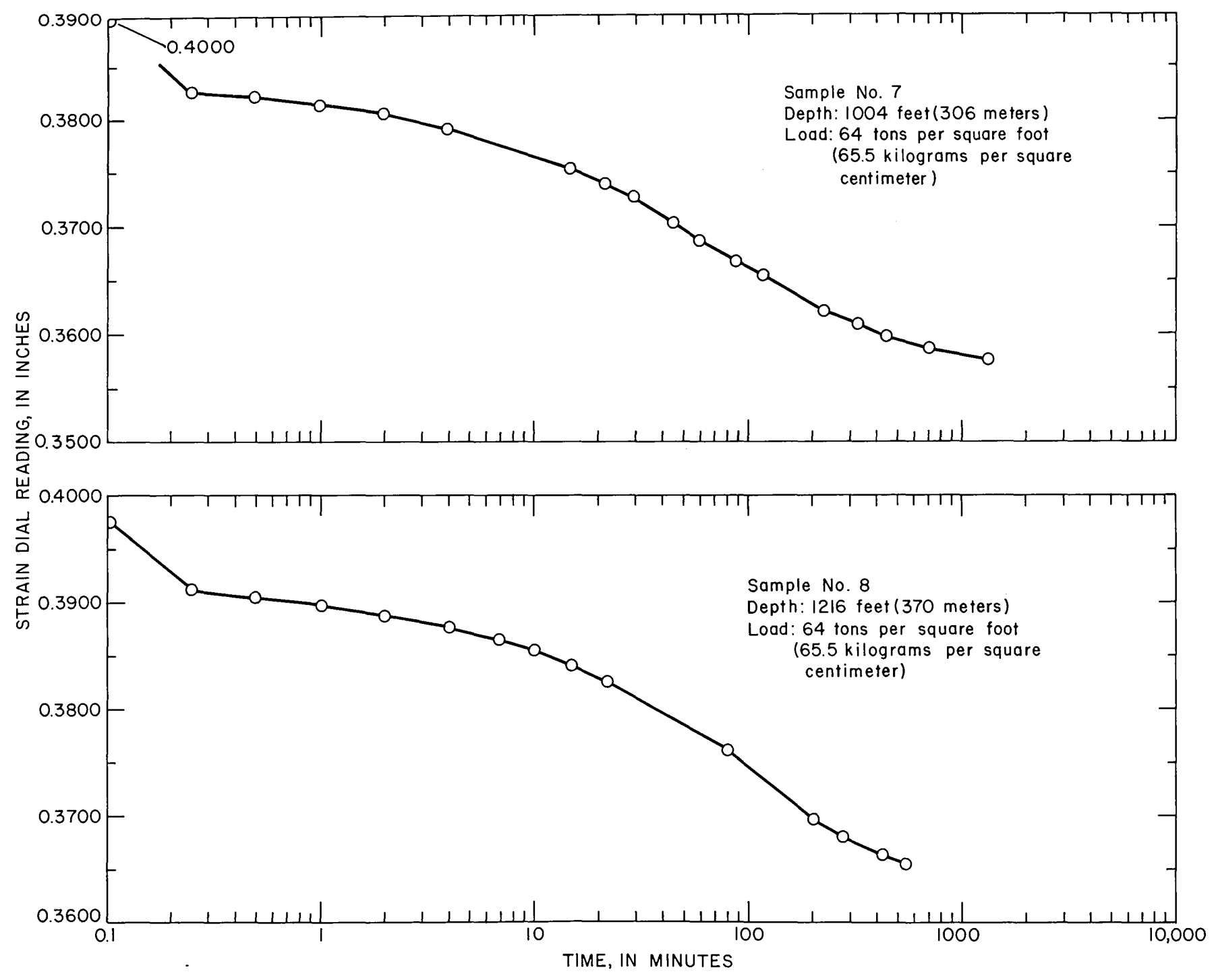

FIGURE 26.-Relation between consolidation and time for clay samples from depths of 1,004 and 1,216 feet (306 and 371 meters) 


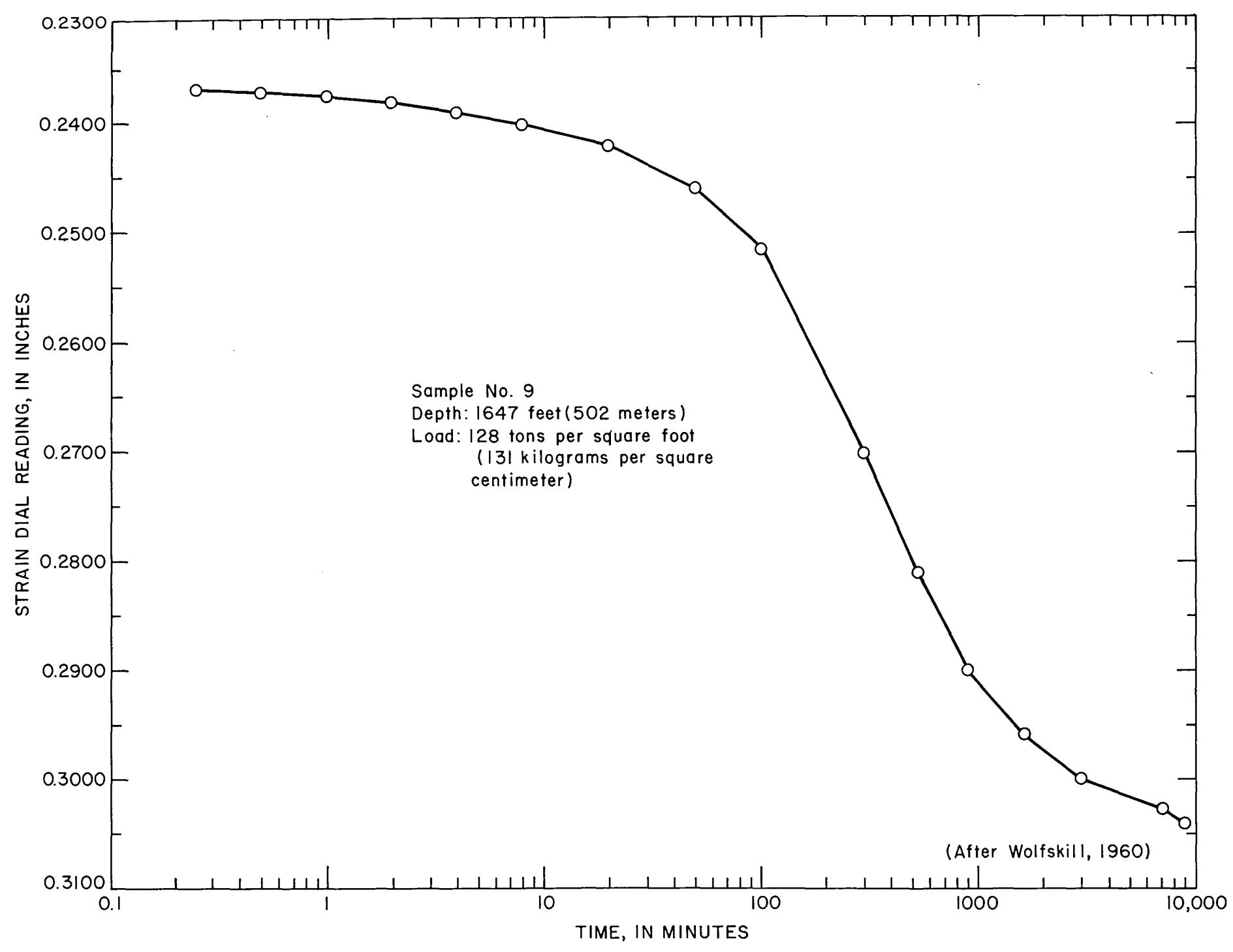

FIGURE 27.-Relation between consolidation and time for a clay sample from a depth of 1,647 feet (502 meters) 